\title{
PODMIEJSKIE LETNISKA ŁODZI W OKRESIE DWUDZIESTOLECIA MIĘDZYWOJENNEGO
}

\begin{abstract}
Wstęp
Pojęcie „letnisko" może być rozumiane dwojako i oznaczać miejscowość lub siedlisko (budynek) położone $\mathrm{w}$ atrakcyjnym przyrodniczo miejscu, np. na obszarze leśnym, w pobliżu zbiornika wodnego, ale niezbyt oddalone od dużego miasta. Powinno być dobrze z nim skomunikowane i odpowiednio zagospodarowane, by umożliwić wygodny wypoczynek w okresie lata. Na letnisko przyjeżdżają przeważnie rodziny z małymi dziećmi, które spędzają tam zwykle co najmniej kilkanaście dni, a niekiedy i całe wakacje.

Ta forma pobytowego wypoczynku podmiejskiego była popularna jeszcze przed I wojną światowa, zwłaszcza wśród średniozamożnych mieszkańców miast. Często wyjeżdżano z całym dobytkiem, przewożonym furmankami do pobliskich wsi, gdzie od zamożniejszych rolników wynajmowano kwatery. Zdarzało się, że stamtąd dojeżdżano do pracy, pozostawiając rodzinę na letnisku.

Funkcja letniskowa trwale zapisała się zarówno w morfologii, jak i fizjonomii miejscowości, które ją pełniły i zlokalizowane były w strefie podmiejskiej Łodzi. Dotychczas prowadzone badania (m.in. LISZEWSKI 1987, MATCZAK 1981, 1982, 1984, 1986, 1987, STEFAŃSKI 1991) wskazuja że okresem
\end{abstract}


najbardziej dynamicznego rozwoju tej funkcji było dwudziestolecie międzywojenne. Jest to jeden $\mathrm{z}$ powodów zainteresowania autorów właśnie tym etapem w historii rozwoju okolic Łodzi. Przełom XX i XXI w. jest okresem, w którym część miejscowości opisanych w opracowaniu ponownie zaczęła być uznawana za miejsca bardzo atrakcyjne nie tylko turystycznie, ale także, ze względu na bliskie położenie miasta centralnego oraz stale polepszająca się dostępność komunikacyjną, jako obszary stałego zamieszkania głównie mieszkańców Łodzi. W części sytuacja ta jest wynikiem działań lokalnych społeczności oraz władz samorządowych, które starają się wykorzystać bogatą "letniskową" historię miejscowości lub ich dzielnic do przyciągnięcia nowych letników, ale także inwestorów, przedsiębiorców (hotelarzy, restauratorów), nowych mieszkańców w celu ożywienia i poprawy jakości życia na zamieszkałych i zarządzanych przez nie obszarach.

Tabela 1. Przynależność administracyjna obszaru (współczesna) i początek pełnienia funkcji wypoczynkowej przez opisane w niniejszym opracowaniu miejscowości do 1939 r.

\begin{tabular}{|c|c|c|c|c|c|c|}
\hline $\begin{array}{l}\text { Nazwa } \\
\text { miejsco- } \\
\text { wości }\end{array}$ & Gmina & $\begin{array}{l}\text { Powiat } \\
\text { (współ- } \\
\text { cześnie) }\end{array}$ & $\begin{array}{l}\text { Odleg- } \\
\text { łość } \\
\text { od } \\
\text { Łodzi } \\
\text { w km }\end{array}$ & $\begin{array}{l}\text { Czas } \\
\text { powstania } \\
\text { miejscowości }\end{array}$ & $\begin{array}{l}\text { Początek } \\
\text { funkcji } \\
\text { wypo- } \\
\text { czynkowej } \\
\text { (rok) }\end{array}$ & Uwagi \\
\hline [1] & [2] & [3] & [4] & [5] & [6] & [7] \\
\hline Arturówek & Łódź & łódzki & - & $\begin{array}{l}\text { przed I wojną } \\
\text { światową }\end{array}$ & $\begin{array}{l}\text { przełom } \\
\text { wieków } \\
\text { XIX i XX }\end{array}$ & $\begin{array}{c}\text { obecnie } \\
\text { w granicach Łodzi }\end{array}$ \\
\hline Grotniki & Zgierz & zgierski & 18 & międzywojnie & 1930 & $\begin{array}{c}\text { osiedle o układzie } \\
\text { wieloosiowym } \\
\text { (kolej kutnowska) }\end{array}$ \\
\hline $\begin{array}{l}\text { Las } \\
\text { Kolumna }\end{array}$ & Łask & Łaski & 22 & międzywojnie & 1927 & $\begin{array}{c}\text { siostrzane osiedle } \\
\text { Tuszyn Lasu - układ } \\
\text { parkowy } \\
\text { (kolej kaliska) }\end{array}$ \\
\hline Łagiewniki & Łódź & łódzki & - & międzywojnie & $1932^{*}$ & $\begin{array}{c}\text { osiedle o układzie } \\
\text { parkowym } \\
\text { (nie zostało } \\
\text { zrealizowane) }\end{array}$ \\
\hline $\begin{array}{l}\text { Nowa } \\
\text { Gdynia }\end{array}$ & Zgierz & zgierski & 8 & międzywojnie & $\begin{array}{c}\text { lata } 30 . \mathrm{XX} \\
\text { w. } \\
\end{array}$ & $\begin{array}{c}\text { obecnie } \\
\text { w granicach Zgierza }\end{array}$ \\
\hline Rogi & Łódź & łódzki & - & $\begin{array}{l}\text { przed I wojną } \\
\text { światową }\end{array}$ & $\begin{array}{l}\text { przełom } \\
\text { wieków } \\
\text { XIX i XX }\end{array}$ & $\begin{array}{c}\text { obecnie } \\
\text { w granicach Łodzi }\end{array}$ \\
\hline Rosanów & Zgierz & zgierski & 15 & międzywojnie & 1930 & $\begin{array}{c}\text { początkowa nazwa } \\
\text { Lućmierz Las } \\
\text { (tramwaj } \\
\text { ozorkowski) }\end{array}$ \\
\hline
\end{tabular}


PODMIEJSKIE LETNISKA ŁODZI W OKRESIE DWUDZIESTOLECIA MIĘDZYWOJENNEGO

\begin{tabular}{|c|c|c|c|c|c|c|}
\hline [1] & [2] & [3] & {$[4]$} & [5] & [6] & [7] \\
\hline Rydzynki & Tuszyn & $\begin{array}{c}\text { łódzki } \\
\text { wschodni }\end{array}$ & 18 & $\begin{array}{l}\text { przed I wojną } \\
\text { światową }\end{array}$ & 1930 & $\begin{array}{c}\text { bliskie sąsiedztwo } \\
\text { Zofiówki i Tuszyna } \\
\text { Lasu } \\
\text { (tramwaj tuszyński) }\end{array}$ \\
\hline $\begin{array}{l}\text { Sokolniki } \\
\text { Las }\end{array}$ & Ozorków & zgierski & 22 & międzywojnie & 1928 & $\begin{array}{c}\text { osiedle o układzie } \\
\text { parkowym } \\
\text { (linia tramwajowa do } \\
\text { Ozorkowa) } \\
\end{array}$ \\
\hline Tuszyn Las & Tuszyn & $\begin{array}{c}\text { łódzki } \\
\text { wschodni }\end{array}$ & 18 & międzywojnie & 1927 & $\begin{array}{l}\text { osiedle o układzie } \\
\text { parkowym - projekt } \\
\text { podobny do osiedla } \\
\text { Las Kolumna } \\
\text { (tramwaj tuszyński) }\end{array}$ \\
\hline $\begin{array}{l}\text { Warchołów } \\
\text { (Nowy } \\
\text { Otwock, } \\
\text { Nowe } \\
\text { Zakopane) } \\
\end{array}$ & Głowno & zgierski & 27 & $\begin{array}{l}\text { przed I wojną } \\
\text { światową }\end{array}$ & $\begin{array}{l}\text { lata } 30 \\
\text { XX w. }\end{array}$ & $\begin{array}{c}\text { obecnie } \\
\text { w granicach Głowna } \\
\text { (kolej kaliska) }\end{array}$ \\
\hline $\begin{array}{l}\text { Wiśniowa } \\
\text { Góra }\end{array}$ & Andrespol & $\begin{array}{c}\text { łódzki } \\
\text { wschodni }\end{array}$ & 13 & $\begin{array}{l}\text { przed I wojną } \\
\text { światową }\end{array}$ & 1920 & $\begin{array}{c}\text { typowy przykład } \\
\text { układu jednoosio- } \\
\text { wego } \\
\text { (kolej fabryczna } \\
\text { Łódź Rokiciny) } \\
\end{array}$ \\
\hline Zofiówka & Tuszyn & $\begin{array}{c}\text { łódzki } \\
\text { wschodni }\end{array}$ & 20 & $\begin{array}{l}\text { przed I wojną } \\
\text { światową }\end{array}$ & 1910 & $\begin{array}{c}\text { jedna z najstarszych } \\
\text { miejscowości } \\
\text { letniskowych } \\
\text { w strefie }\end{array}$ \\
\hline
\end{tabular}

Źródło: opracowanie autorów.

Nie jest ambicją autorów wyznaczanie granic funkcjonalnej strefy podmiejskiej Łodzi, dlatego też jako obszar opracowania przyjęto miejscowości letniskowe położone $\mathrm{w}$ odległości ok. $30 \mathrm{~km}$ od centrum miasta (tab. 1, rys. 1). Jest to o tyle uzasadnione, że w większości przypadków tak delimitowany obszar pokrywa się w zasadniczej części z terenami, które wg różnych autorów zaliczane są do strefy podmiejskiej Łodzi (LISZEWSKI 1987, MATCZAK 1981, 1984, 1986, 1987), aglomeracji łódzkiej, Łódzkiego Obszaru Metropolitalnego (LISZEWSKI 2010), czy wreszcie do Turystycznego Regionu Metropolitalnego Łodzi (LISZEWSKI 2005, WILUŚ, LISZEWSKI 2010). 


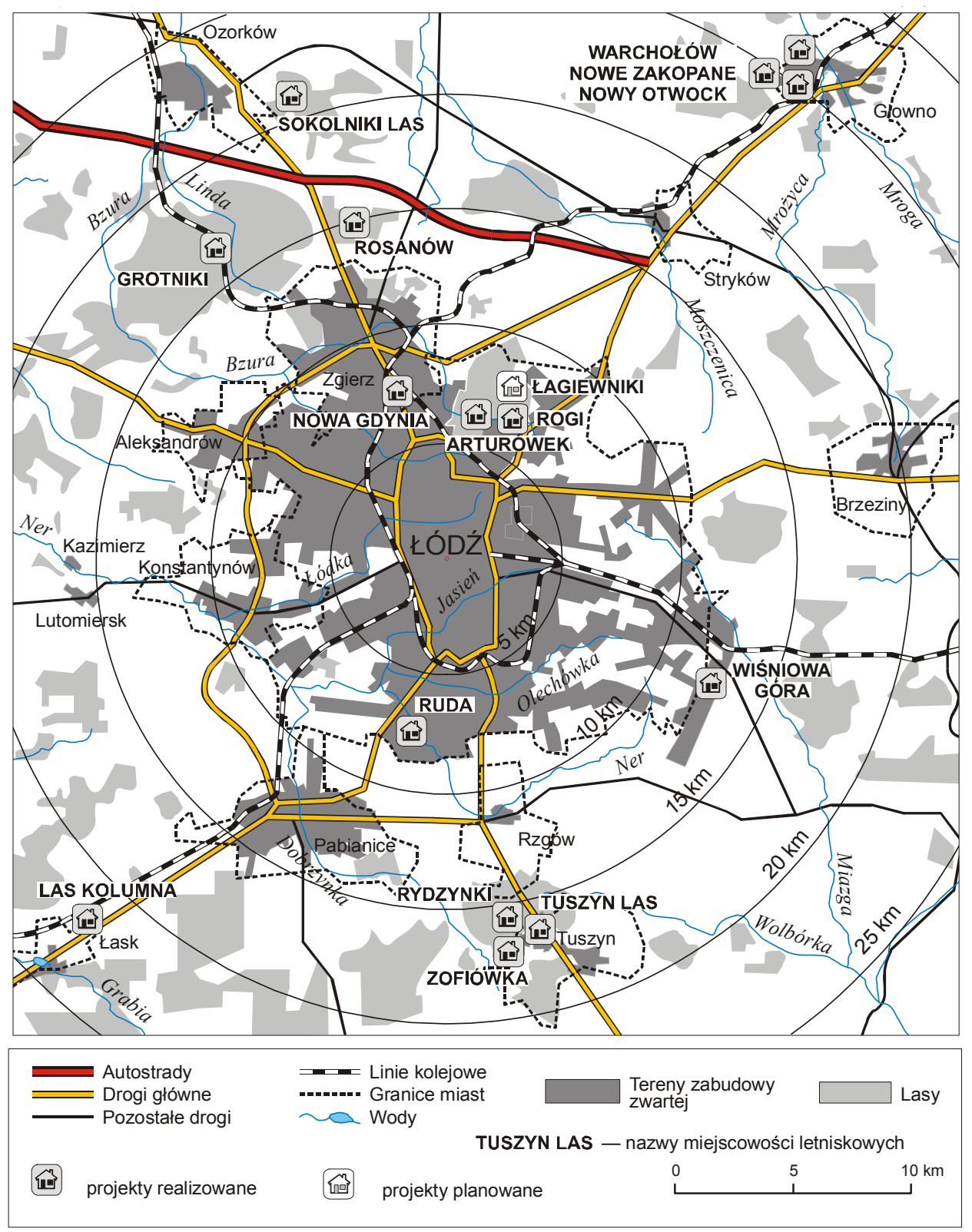

Rys. 1. Lokalizacja miejscowości letniskowych w strefie podmiejskiej Łodzi do $1945 \mathrm{r}$. na tle współczesnego rozmieszczenia lasów i sieci komunikacyjnej Źródło: opracowanie autorów 


\section{Geneza i uwarunkowania powstania}

Na powstanie najstarszych osiedli, a tym samym na rozwój terenów wypoczynkowych wg LISZEWSKIEGO (1987) wywarł wpływ poziom zamożności społeczeństwa, wzrost świadomości społecznej, trudne warunki życia w mieście ${ }^{1}$, dostępność komunikacyjna i prawna gruntów, a także walory środowiska naturalnego - szczególnym zainteresowaniem cieszyły się obszary suche, piaszczyste, porośnięte lasem iglastym, położone niedaleko rzeki. Z czasem już nie walory terenu, a możliwości kupna ziemi zaczęły decydować o tworzeniu nowych osiedli letniskowych.

Początki rozwoju funkcji wypoczynkowej w okolicach Łodzi sięgają okresu sprzed I wojny światowej. Wypoczynek cotygodniowy ludności miejskiej na pobliskich terenach wiejskich rozpowszechnił się $w$ drugiej połowie XIX w. Miał on związek albo z budową rezydencji przez najbogatszą część mieszkańców (np. w Grotnikach, Rąbieniu AB, Tworzyjankach, Zofiówce, Sokolnikach, Rudzie), albo z wyjazdami średnio zamożnych na tzw. „letniska" (polegało to na wynajmowaniu kwater w czasie lata u rolników, np. w Wiśniowej Górze, Tuszynie, Zofiówce, Rydzynkach). Najchętniej wybierano obszary atrakcyjne przyrodniczo, tj. zalesione, położone $\mathrm{w}$ niedalekiej odległości od miasta, z dobrą dostępnością komunikacyjną ${ }^{2}$. W tym czasie najbiedniejsza część społeczeństwa organizowała sobie krótkotrwały wypoczynek w parkach, pobliskich lasach i na terenach przywodnych.

Rozwojowi letnisk w początkach XX w. sprzyjały liczne inwestycje związane z poprawą dostępności komunikacyjnej, m.in. budowa linii kolejowych oraz sieci tramwajów podmiejskich, a także nowe uregulowania prawne umożliwiające parcelacje majątków ziemskich i gruntów należących do miast i osiedli. Prawdopodobnie nie bez znaczenia było także uzyskanie przez Łódź statusu miasta wojewódzkiego (rys. 2).

W dwudziestoleciu międzywojennym nastąpił intensywny rozwój funkcji wypoczynkowej w strefie podmiejskiej Łodzi. Wiązał się on z powstawaniem osiedli letniskowych zarówno $\mathrm{w}$ starszych miejscowościach, jak i na tzw. ",surowym korzeniu” (takich jak Sokolniki, Grotniki, Kolumna, Tuszyn Las), wzorowanych na miastach ogrodach E. Howarda. Wznoszono na nich

\footnotetext{
${ }^{1}$ Dotyczyło to m.in. złych warunków mieszkaniowych: zabudowa w mieście była zwarta, zakłady przemysłowe sąsiadowały często bezpośrednio z domami mieszkalnymi, zanieczyszczenie powietrza substancjami szkodliwymi (gazy, pyły) było wysokie, a wśród zabudowań znajdowało się mało zieleni (BEDNARSKA, MUSIAŁ 1973).

2 W słabej dostępności komunikacyjnej, a przede wszystkim w braku połączeń kolejowych, zachodniego sektora strefy podmiejskiej Łodzi, SZKUP (2003) upatruje późnego rozwoju tam osadnictwa turystycznego, przypadającego dopiero na połowę lat 60. XX w.
} 


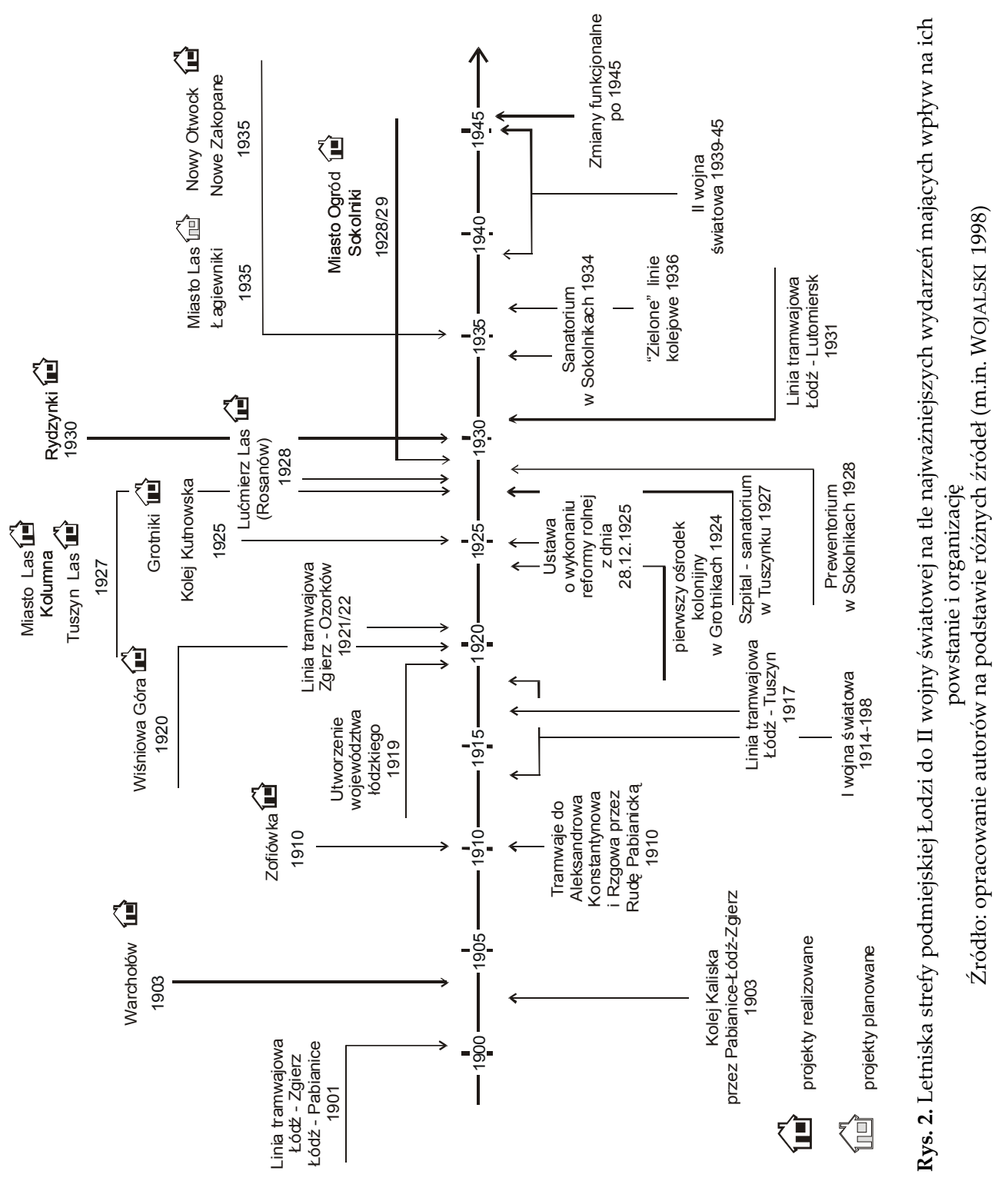


„drugie domy”, których pierwowzorem - zdaniem STEJSKAŁA (1992) - były rezydencje podmiejskie burżuazji łódzkiej. Na początku XX w. liczba tego typu obiektów szybko wzrastała, ale - jak piszą WARSZYŃSKA i JACKOWSKI (1978) - straciły one charakter monumentalny na rzecz skromnych i prostych pomieszczeń, gdyż ich właścicielami stawali się także ludzie mniej zamożni.

Po II wojnie światowej wiele miejscowości letniskowych (np. Tuszyn Las) zamieniono na osiedla mieszkaniowe dla napływających do Łodzi osadników; niektóre domy i wille przekształcono natomiast w zakładowe ośrodki wypoczynkowe i kolonijne (m.in. w Wiśniowej Górze i Grotnikach). Dopiero $\mathrm{w}$ połowie lat 60. XX w. na nowo rozpoczęło się żywe zainteresowanie wypoczynkiem podmiejskim na własnej działce. Osadnictwu sprzyjały dokonywane parcelacje gruntów rolnych, również w sąsiedztwie dawnych osiedli letniskowych (tak powstały m.in. Janówka i Justynów położone niedaleko Wiśniowej Góry).

\section{Inspiracje i pomysły}

Oryginalna koncepcja podmiejskich osiedli letniskowych nawiązywała do popularnej wtedy także w Polsce idei budowy miast ogrodów wylansowanej na przełomie XIX i XX w. przez angielskiego planistę Ebenezera Howarda, który w 1898 r. opublikował książkę pt. To-morrow: A Paceful Path to a Real Reform, a trzy lata później ukazała się jej druga edycja nosząca tytuł Garden Cities of To-morrow. Opracowanie to wielokrotnie wznawiano i przetłumaczono na wiele języków, co przyczyniło się do jego popularyzacji również za granicą.

Miasto ogród wg Howarda winno być samodzielne - przemysłowe, rolnicze, mieszkaniowe - zaplanowane dla co najmniej 30 tys. osób, otoczone szerokim pasem otwartych pól (rys. 3). Dzięki temu miało łączyć dodatnie strony miasta i wsi, "torując drogę ruchowi narodowemu, mającemu hamować wyludnienie wsi i przepełnienie i tak już gęsto zaludnionych miast" (DOBRZYŃSKI 1914, s. 458).

Idee E. Howarda realizowano najpierw w pobliżu Londynu - w Letchworth (1903 r.) oraz w Welwyn Garden City (1920 r.) $)^{3}$. Oba miasta miały układy o regularnych kształtach, pełne były zieleni i placów wewnątrz osiedla, a otaczały je pasy zieleni i pól uprawnych niezmniejszone na rzecz zabu-

\footnotetext{
3 www.hertfordshire-genealogy.co.uk/data/places/letchworth.html, www.cyberium.co.uk/park history/welwyn.html.
} 
dowy (KIEŁCZEWSKA-ZALESKA 1972). Następnie miasta ogrody powstały wokół Paryża (1911-1912), w Niemczech (1912 i 1930 r.), w Rosji (wokół Moskwy w 1923 r.), a nawet w Japonii (w pobliżu Tokio w 1918 r.), w Stanach Zjednoczonych oraz południowej Afryce (w latach 1908-1920). Oprócz tego zakładano je w Austrii, Hiszpanii, Luksemburgu, Rumunii, Turcji i we Włoszech. Pomysły Howarda przybierały z czasem różną postać i szerokie zastosowanie $\mathrm{w}$ planowaniu miast. $\mathrm{W}$ późniejszym okresie znalazły również oddźwięk w Polsce, np. miasto ogrodowe Lwów, Podkowa Leśna i Milanówek pod Warszawa, Puszczykowo koło Poznania (PrZYBySz 2009), Giszowiec w Katowicach.

W Polsce początki rozwoju howardowskiego nurtu urbanistycznego sięgają 1909 r., kiedy w Warszawie zaczęła funkcjonować Delegacja ds. Miast Ogrodów, a później Towarzystwo Mieszkań Stałych i Przedmieść Ogrodów. Ważnym propagatorem budowy takich osiedli było Polskie Towarzystwo Higieniczne, pragnące nimi otoczyć duże miasta. W 1913 r. powstał projekt pierwszego w kraju, położonego obok Warszawy, miasta ogrodu Podkowa Leśna. W pobliżu stolicy planowano również realizację koncepcji Howarda w Otwocku, Młocinach, Ostoi, Włochach, Utracie, Ząbkach (www.warszawa. sarp.org.pl). Z czasem miasta ogrody pojawiły się także wokół innych miast, m.in. Częstochowy (Żarki), Katowic (Giszowiec), Wrocławia (Komorowo) i Łodzi (Kolumna, Tuszyn, Grotniki, Sokolniki).

W podłódzkich miastach ogrodach idee Howarda przeszły istotną transformację w wyniku przystosowania ich do wymogów rzeczywistości polskiej w okresie międzywojennym. BARANOWSKA (2005) badająca realizację koncepcji angielskiego planisty na tym obszarze twierdzi nawet, że nie ma w strefie podmiejskiej Łodzi klasycznych przykładów miast ogrodów, a jedynie są ich modyfikacje. Powstałe w latach 20. i 30. XX w. miejscowości różniły się od wytycznych E. Howarda przede wszystkim pełnionymi funkcja$\mathrm{mi}$ - nie spełniono tam założeń ich samowystarczalności, tj. nie rozbudowano strefy przemysłowej i rolniczej, nie wykształciło się zaplecze instytucjonalne, nie wszystkie miały dogodne połączenia komunikacyjne ani nie osiągnęły zakładanej liczby mieszkańców. Dlatego nie utworzyły one niezależnych, ale powiązanych ze sobą jednostek, w których zlokalizowane byłyby usługi i przemysł lekki. Zachowały jednak ideę życia człowieka w przyjaznym otoczeniu. Ich specyfiką było ograniczenie się do pełnienia jedynie funkcji wypoczynkowej lub sypialnianej, więc nie były to klasyczne miasta ogrody, a raczej osiedla satelity ${ }^{4}$. Sokolniki Las i Grotniki powstały właśnie

\footnotetext{
${ }^{4}$ Według SMOGORZEWSKIEGO (1965), osiedle satelita zlokalizowane jest w pobliżu dużego miasta i ma z nim dogodne połączenia środkami komunikacji masowej, co umożliwia mieszkańcom dojazdy 
jako letniska wzorcowe, wzorowane na wytycznych koncepcji budowy miast ogrodów.

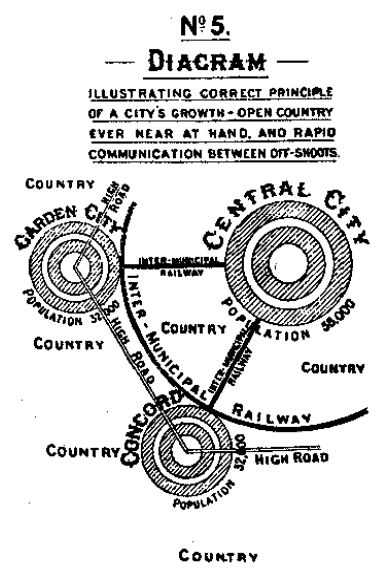

Rys. 3. Rozmieszczenie miast ogrodów względem miasta centralnego wg HOWARDA (1965)

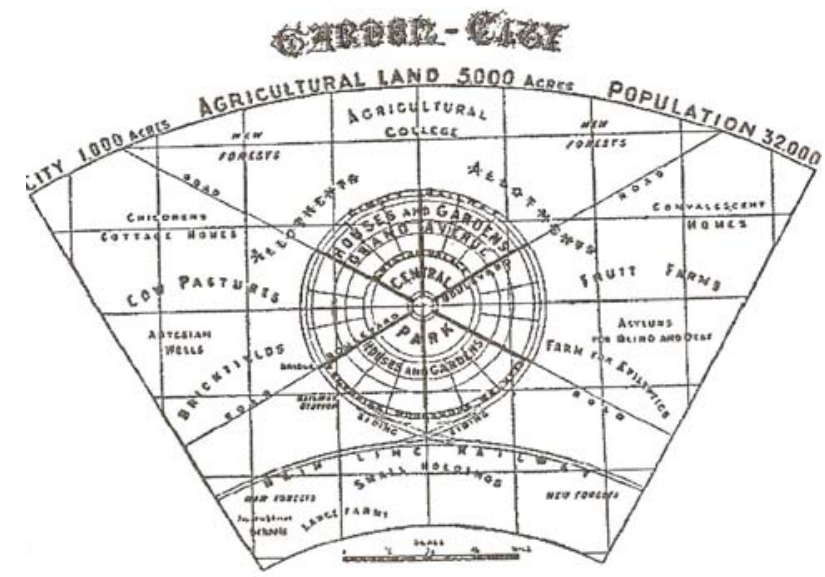

Rys. 4. Projekt miasta ogrodu wg HOWARDA (1965)

Na gruncie krajowym bardzo ważnym krzewicielem idei Howarda był dr Władysław Dobrzyński. Gorąco popierał on budowę miast ogrodów, która miała dążyć do przeciwdziałania nadmiernemu zagęszczeniu ludzi w miastach oraz usunięcia grozy ówczesnych czasów, czyli zakaźnej gruźlicy - choroby mieszkaniowej. Była ona bardzo powszechna na przełomie XIX i XX w., a jej rozprzestrzenianiu się sprzyjały nadmiernie zagęszczone domostwa i panujące $w$ nich niedostateczne warunki higieniczne (mała przestrzeń, wilgoć, kurz, niedobór światła, insekty). Podobne warunki można było spotkać w większości miejsc pracy. „Szczególnie w naszym klimacie, gdzie większą część życia mieszczanin przepędza w przestrzeniach zamkniętych, dobre mieszkanie ma niesłychanie ważne znaczenie dla zdrowia fizycznego, duchowego i etycznego narodu naszego." (DOBRZYŃSKI 1911, s. 830). Cytowany autor - lekarz medycyny - zalecał chorym, oprócz dobrego odżywiania, higienicznego trybu życia, odpowiednie warunki mieszkaniowe, ruch i przebywanie na świeżym powietrzu. Za najlepszy sposób walki z gruźlicą uważał jednak przenoszenie rodzin robotniczych, jak to okreś-

do pracy i usług. Mieszkalnictwo jest podstawową funkcją miasta satelity, a inne są słabo rozwinięte na korzyść miasta macierzystego lub nie występują. 
lał: „z ciasnych i cuchnących” mieszkań wielkomiejskich do siedzib „pełnych powietrza i światła", a więc miast ogrodów.

Właśnie w takich nowych, planowo zakładanych osiedlach, położonych blisko miast, ale jednocześnie umożliwiających kontakt z przyroda, miały zamieszkać na stałe różne warstwy ludności. Jak twierdził DOBRZYŃSKI (1911), to zaspokoiłoby ich "głód czystego powietrza". Jednocześnie miasta ogrody tworzone byłyby na tanich terenach podmiejskich, dobrze skomunikowanych z miastem. Tam powstałyby skromne, ładne, schludne domki „w swojskim stylu" dla pracujących fizycznie i umysłowo. Mieszkania podmiejskie miały być tanie, "dla szerokich warstw obywateli różnego stanu i zamożności". To pozwoliłoby na oszczędności w budżetach domowych (które mogłyby być przeznaczane np. na cele kulturalne) i na gromadzenie funduszy na cele komunalne (użyteczności publicznej). W rezultacie sprawić to miało, że: „W jaskiniowcu wielkomiejskim, żyjącym bez światła, powietrza i przestrzeni, rozbudzi się uświadomione indywiduum, które nie tylko będzie rozkoszować się życiem, ale chętniej i intensywniej pracować." (DOBRZYŃSKI 1911, s. 836). Jednocześnie współżycie ludzi należących do różnych warstw społecznych i współpracujących ze sobą na rzecz osiedla, miało przyczynić się do demokratyzacji wzajemnych relacji społecznych $w$ ramach osiągania wspólnego celu. Niestety część tych szczytnych idei do dziś nie została zrealizowana ze względu na ich (przynajmniej częściowo) utopijny charakter.

\section{Układy przestrzenne miejscowości}

Koncepcja urbanistyczna miasta ogrodu zakładała, że będzie ono regularne, o powierzchni ok. 6000 akrów (tj. prawie 2,5 tys. ha) i zamieszkiwane przez mniej więcej 30 tys. osób. Powinno mieć układ pierścieniowy, z centrum w kształcie okręgu (wielkości ok. 400 ha). Tam przewidziano przestrzeń na ogród - Centralny Park Publiczny - otoczony szklaną arkadą (Crystal Palace), pełniącą częściowo funkcje targowiska, oraz na tzw. miejską halę, wyposażoną m.in. W aulę, bibliotekę, teatr, muzeum i szpital. $Z$ centrum układu promieniście wybiegały ulice dzielące miasto na sześć równych sobie części (rys. 4). Wytyczono również wokół centrum pierścieniowo ułożone aleje, przy których powinny zostać usytuowane budynki mieszkalne, o podobnych wymiarach, lecz urozmaiconej architekturze. Środkowy pierścień, nazywany Grand Avenue, szerszy od pozostałych, tworzyłby dodatkowy pas zieleni, przy którym przewidziano miejsce na budynki użyteczności publicznej (np. 
kościoły, szkoły). Przy alei zewnętrznej, a więc jednocześnie w pobliżu głównej linii kolejowej (elektrycznej), miały się mieścić różnorodne obiekty przemysłowe i magazyny. W strefie dalszej zaplanowano szeroki pas otwartych pól uprawnych, sadów i ogrodów. Howardowskie miasta ogrody, pełniące funkcje przemysłowe, rolnicze, mieszkaniowe i inne, wyposażone także w różnorodne usługi i liczne miejsca pracy, powinny odznaczać się - jak już wcześniej wspomniano - samodzielnością.

Podział podmiejskich gruntów rolnych i leśnych na cele wypoczynkowe mógł odbywać się jednorazowo, w wyniku planowej akcji parcelacyjnej, albo stopniowo. W pierwszym przypadku powstawały przeważnie osiedla o regularnych, geometrycznych kształtach (m.in. Sokolniki Las), w drugim - nieregularne, co wynikało zazwyczaj z etapowości wydzielania działek, rzadziej z fizjografii terenu.

W okresie międzywojennym działki i miejscowości zakładano najczęściej na tzw. „surowym korzeniu”, dlatego możliwe było zrealizowanie regularnego planu, będącego wynikiem koncepcji urbanistycznej, rozwiązującej potrzeby życia miejskiego i jednocześnie nawiązującej do idei miast ogrodów. Wytyczano podobnej wielkości działki, symetrycznie biegnące drogi, a niekiedy także place. Rozplanowanie przestrzenne miejscowości uzyskiwało układ szachownicowy, promienisty lub parkowy (rys. 5) (np. Kolumna Las, Miasto Ogród Sokolniki) - będący połączeniem dwóch pierwszych (MATCZAK 1982). Tych kompozycji nie zmieniły nawet pojawiające się z czasem wtórne podziały geodezyjne, gdyż wpisały się one w już istniejące układy.

Przykładowo, w Sokolnikach zakładano powstanie, oprócz ogromnej liczby działek, wielu zielonych skwerów, alei, placów publicznych i innych obiektów tworzących zaplecze gospodarcze i rekreacyjne. Zaplanowano m.in. wybudowanie kilku szkół i przedszkoli, szpitala, hoteli, kasyna, kino-teatru, remizy tramwajowej, postoju autobusów, zajezdni samochodowej, parków, boisk, stadionu, strzelnicy, toru łuczniczego, pływalni, magistratu, zarządu letniska, domu ludowego, posterunku policji, straży ogniowej, elektrowni, hali targowej. Część planów udało się zrealizować w szybkim czasie, np. boisko sportowe, kościół, rynek. Niestety w czasie i po II wojnie światowej większość budowli uległa zniszczeniu. Mimo to nadal w planie Sokolnik wyraźnie widoczne są ślady dawnych założeń miasta ogrodu (MAKOWSKA 2002).

Miejscowości wypoczynkowe lokalizowane na terenach rolniczych lub rolno-leśnych otaczających Łódź miały inne rozplanowanie przestrzenne. Intensywna parcelacja wiązała się z przekształcaniem pierwotnego siedliska i rozłogów wiejskich. Kiedy przemiany te były pełne, a tereny rekreacyjne dostosowały się do istniejących układów przestrzennych, powstały osiedla 


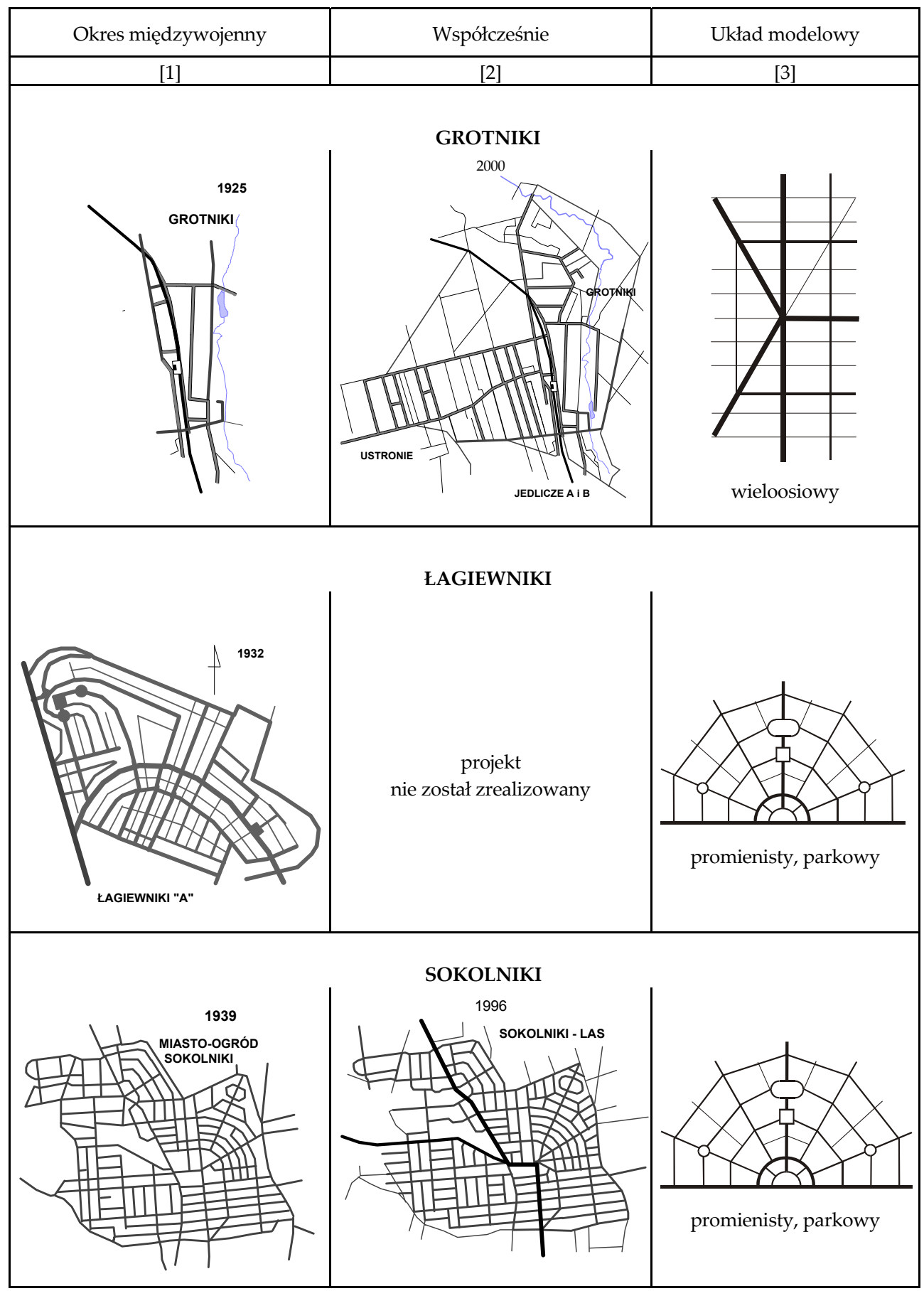

94 WARSZTATYZ ZGEOGRAFI TURYZMU 
PODMIEJSKIE LETNISKA ŁODZI W OKRESIE DWUDZIESTOLECIA MIĘDZYWOJENNEGO

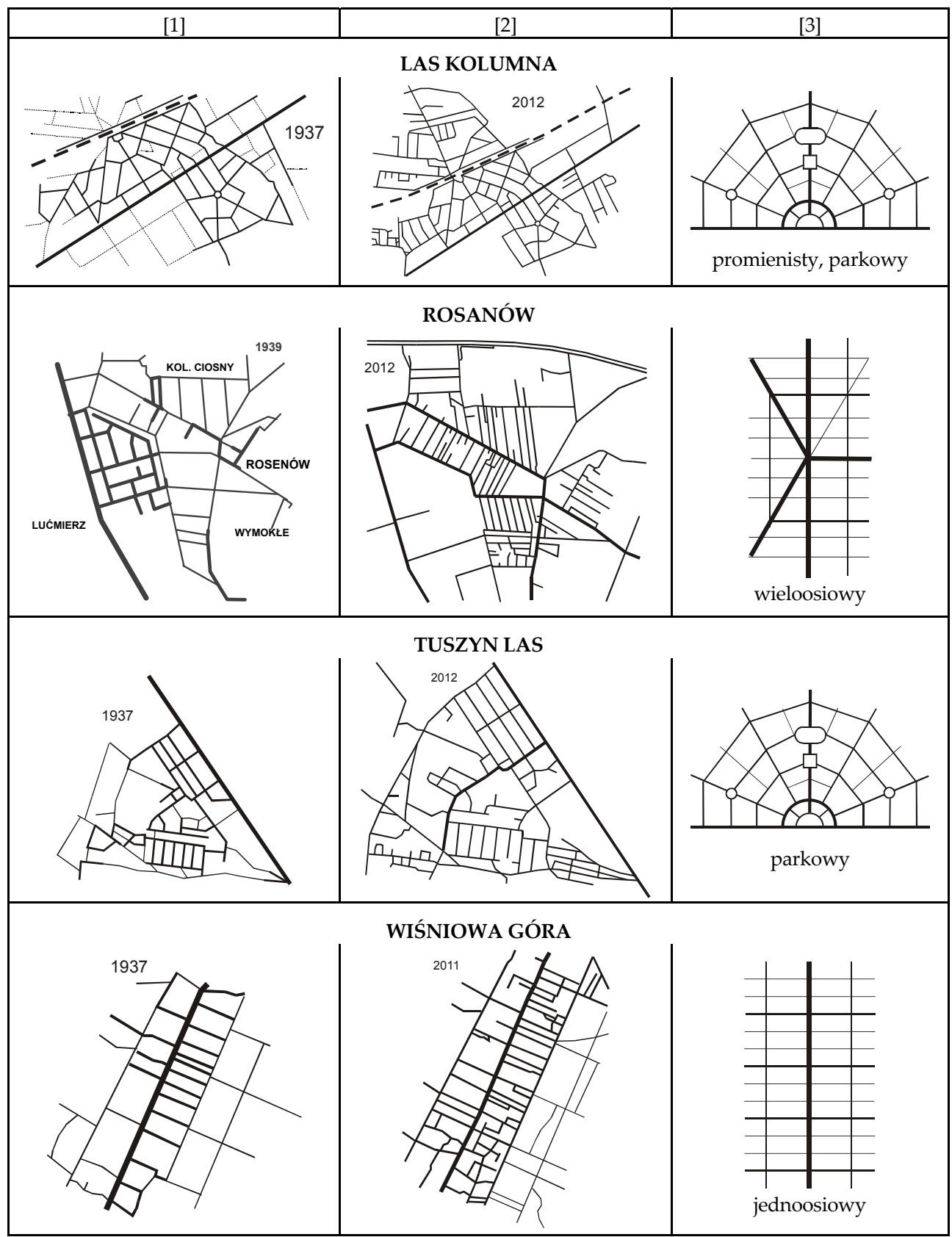

Rys. 5. Układy przestrzenne wybranych miejscowości letniskowych strefy podmiejskiej Łodzi w ujęciu historycznym i modelowym

Źródło: opracowanie autorów na podstawie map topograficznych oraz badań terenowych; typologia układów przestrzennych na postawie: MATCZAK (1984) 
jednoosiowe (np. Wiśniowa Góra) lub wieloosiowe (np. Grotniki). Zachowały się one do dziś, podobnie jak ich układy komunikacyjne (rys. 5). Natomiast w sołectwach, w których przekształcenie siedliska i rozłogów wiejskich pod wpływem lokalizacji działek letniskowych było niepełne i ewolucyjne, wytworzyły się wg MATCZAKA $(1982,1984,1987)$ układy wieloosiowe, z jednym lub dwoma skupieniami działek (np. Rosanów), jednoosiowe w większości zajęte przez działki - oraz mozaikowe (rys. 5).

\section{Organizacje społeczne}

W roku 1899 E. Howard założył Stowarzyszenie Miast Ogrodów (Garden Cities Association), funkcjonujące do dzisiaj pod nazwą Stowarzyszenie na rzecz Planowania Miast i Wsi (Town and Country Planning Association). Podobnie $\mathrm{w}$ okolicach Łodzi tradycje zakładania organizacji społecznych są długie i sięgają międzywojnia, a więc początków powstawania miejscowości wypoczynkowych. Do najstarszych należało Towarzystwo Obrony Środowiska w Grotnikach (założone w 1928 r.) oraz Stowarzyszenie Właścicieli Nieruchomości Miasta Ogrodu Sokolniki (funkcjonujące od 1929 r.). Pierwsze z nich przestało już istnieć, drugie - po przerwie w działalności - reaktywowano. Stowarzyszenia ${ }^{5}$ tworzone były $\mathrm{z}$ myślą działania na rzecz miejscowości i lokalnych społeczności, początkowo m.in. poprzez racjonalne parcelowanie gruntów i rozbudowę infrastruktury, z uwzględnieniem ochrony środowiska naturalnego, a następnie także upowszechniania rekreacji, rozrywki i kultury. W ten sposób znacząco aktywizowały one i promowały podmiejskie obszary turystyczne. Współdziałanie osób dawało większą szansę na uzyskanie konkretnych i wymiernych korzyści, dlatego stowarzyszenia reprezentujące najniższy szczebel samorządności przyczyniły się do integracji ludzi oraz $\mathrm{w}$ istotny sposób zadecydowały o charakterze i wyglądzie tego obszaru (MAKOWSKA-ISKIERKA 2009). W podmiejskich osiedlach letniskowych ludzie odnajdują czas na podtrzymanie i rozwijanie kontaktów międzyludzkich, co dowodzi stwierdzenia DOBRZYŃSKIEGO (1914, s. 669), że „człowiek jest stworzeniem towarzyskim, a życie wielkomiejskie izoluje i zo-

${ }^{5}$ Współcześnie w podłódzkich miejscowościach wypoczynkowych działa m.in. Stowarzyszenie Proekologiczne Grotniki - Jedlicze - Ustronie, o nazwie „Pinia”, Towarzystwo Rozwoju Grotnik, Towarzystwo Przyjaciół Rosanowa i okolic, Gminny Ludowy Klub Sportowy „Andrespolia” w Wiśniowe Górze, a w Sokolnikach Lesie Fundacja Ekologiczna, Stowarzyszenie Właścicieli Działek Leśnych oraz Towarzystwo Przyjaciół Miasta Ogrodu Sokolniki.

96 WARSZTATYZGEOGRAFII TURYZMU 
bojętnia go na losy bliźnich; w przedmieściach ogrodach zaś współżycie zbliża ludzi i wygładza nierówności socjalne".

\section{Zarys historii}

W drugiej połowie XIX w. w związku z pogarszającymi się warunkami życia w mieście (na skutek przede wszystkim rozwoju przemysłu i gwałtownego wzrostu liczby mieszkańców), a także dzięki rozwojowi komunikacji masowej (zwłaszcza szynowej ułatwiającej dostęp do atrakcyjnych przyrodniczo terenów, głównie leśnych i suchych albo położonych nad ciekami wodnymi) zrodziła się potrzeba wypoczynku poza miejscem zamieszkania. Pojawiła się wówczas nowa forma przemieszczeń turystycznych związanych z wypoczynkiem cotygodniowym, obok popularnych już wcześniej wśród zamożniejszych mieszkańców wyjazdów na urlopy do polskich i zagranicznych uzdrowisk, kurortów i kąpielisk (m.in. Szwajcarii, Austrii, Francji, Włoch, Ostendy) oraz wyjazdów poznawczych (do Włoch, Francji, Anglii).

Poza granicami miasta na terenach niezbyt oddalonych od miejsca stałego zamieszkania, ale $\mathrm{w}$ otoczeniu zieleni, powstawały rezydencje o wysokim standardzie należące do najbogatszych łodzian, tj. przemysłowców, handlowców, bankierów. Wykupywali oni majątki ziemskie od bankrutującej szlachty, aby w swych nowych reprezentacyjnych posiadłościach wypoczywać, a także przyjmować gości.

W latach 80. XIX w. baron Juliusz Heinzel kupił folwark Julianów w Radogoszczu (leżący wówczas poza granicami miasta) oraz dobra Łagiewnickie od Zawiszów, gdzie zbudował pałace-rezydencje. Podobnie ok. 1912 r. na terenie dzisiejszego Głowna powstała rezydencja (pałacyk) Roemischa. Podmiejskie posiadłości ziemskie wraz z okazałymi siedzibami letnimi posiadali też inni łódzcy fabrykanci, m.in. Poznańscy na Kozinach, Herbstowie w Sokolnikach (ok. 1905 r.), Silbersteinowie w Lisowicach.

Do pierwszych osiedli wypoczynkowych zaliczyć można ponadto Arturów (dzisiaj Arturówek) i Rogi w Lesie Łagiewnickim oraz Rudę Pabianicką stanowiącą obecnie południowo-zachodnią część Łodzi, w których powstawały obiekty letniskowe (LISZEWSKI 1987).

W tym czasie odbywały się również, głównie latem, wyjazdy osób średniozamożnych na tzw. letniska na otaczające Łódź tereny wiejskie (m.in. do Wiśniowej Góry, Tuszyna, Zofiówki, Rydzynek, Głowna). Były to przyjazdy jednodniowe lub dłuższe pobyty rodzinne, nawet kilkutygodniowe, $\mathrm{z}$ noc- 
legiem w wynajmowanych $\mathrm{u}$ rolników mieszkaniach. Opisany proces wynajmowania kwater uznany został przez LISZEWSKIEGO (1987) za pierwszą formę ekspansji funkcji wypoczynkowej na tereny podmiejskie.

Większość łodzian, pochodząca z najbiedniejszych warstw społecznych, wybierała krótki, kilkugodzinny wypoczynek w pobliskich lasach, nad wodą lub w parkach miejskich (np. Zródliska, Wenecja, Mania, na Młynku), ale te formy rekreacji nie przyczyniły się do powstania żadnych nowych form osadniczych.

Okres I wojny światowej zahamował rozwój osadnictwa wypoczynkowego w otoczeniu Łodzi aż do momentu odzyskania przez Polskę niepodległości. Dopiero w czasie dwudziestolecia międzywojennego na terenach podmiejskich (znanych $\mathrm{z}$ wcześniejszych wyjazdów na letniska) zaczęły powstawać działki rekreacyjne oraz nowe osiedla letniskowe. Parcelacje i sprzedaż gruntów ułatwiała Ustawa $z$ dnia 28 grudnia 1925 r. o wykonaniu reformy rolnej ${ }^{6}$ regulująca sytuację tak, że w okręgach przemysłowych i podmiejskich w rękach prywatnych miały pozostawać majątki o powierzchni do 60 ha, zaś wszelką nadwyżkę właściciele mieli obowiązek parcelacji i sprzedaży po cenach rynkowych w określonym terminie. Ustawa przyczyniła się do wyprzedaży ziemi i powstania nowych dzielnic letniskowych (np. w Głownie na gruntach A. Komorowskiej - Nowe Zakopane, a Lemańskich - Nowy Otwock). Przemieszczeniom ludności sprzyjał też dalszy rozwój kolei i tramwajów podmiejskich, ogólna poprawa poziomu życia oraz wzrost zapotrzebowania na wypoczynek.

Podobnie jak $\mathrm{w}$ poprzednim okresie powstawały podmiejskie rezydencje burżuazji łódzkiej m.in. w Grotnikach i Kęblinach (pierwowzór popularnych później „drugich domów”), które były wzorem do naśladowania także dla osób mniej zamożnych i inteligencji, przez co straciły swój monumentalny charakter. Nadal wynajmowano kwatery u bogatych rolników lub w pensjonatach (m.in. w Głownie i Wiśniowej Górze), albo wypoczywano krócej nad wodą i w otoczeniu lasów. Intensywny rozwój funkcji wypoczynkowej miał jednak w tym czasie związek $\mathrm{z}$ powstawaniem osiedli letniskowych w okolicach Łodzi. Zakładano je z inicjatywy osób prywatnych i władz miasta na tzw. „surowym korzeniu”, tj. w sposób planowy i uporządkowany

\footnotetext{
${ }^{6}$ Nadwyżki gruntów położone w promieniu $10 \mathrm{~km} \mathrm{w}$ linii prostej od centrum Łodzi mogły być kupione przez samorządy i instytucje miejskie albo państwo i przeznaczone na rozszerzenie miast, tworzenie gospodarstw podmiejskich i osiedli dla robotników, rzemieślników czy urzędników. Ustalono, że obszar parceli rzemieślniczej wiejskiej nie może przekraczać 2 ha, a przy miastach i ośrodkach przemysłowych parceli robotniczej, urzędniczej itp. 1 ha. Ustawa, która zaczęła obowiązywać od 9 stycznia 1926 r., oprócz tworzenia kolonii i ogródków, m.in. robotniczych i urzędniczych w pobliżu miast oraz ośrodków przemysłowych, określała również kolejność kandydatów przy parcelacji gruntów. Uregulowano ponadto ceny oraz pomoc finansową dla nabywców działek.
} 
na parcelowanych gruntach leśnych oraz częściowo rolniczych położonych blisko linii tramwajów podmiejskich lub kolei (np. Kolumna, Sokolniki, Tuszyn Las, Grotniki). Parcelacje ziemi na działki wypoczynkowe, ale także budowlane i produkcyjne rozpoczęto w Grotnikach w 1925 r. Początkowo objęły one 38 ha gruntów należących do Jasieńskich. W 1928 r. podzielono także grunty Jungowskich. Nabywcami działek położonych w lesie iglastym nad rzeką Lindą byli głównie mieszkańcy miast aglomeracji łódzkiej.
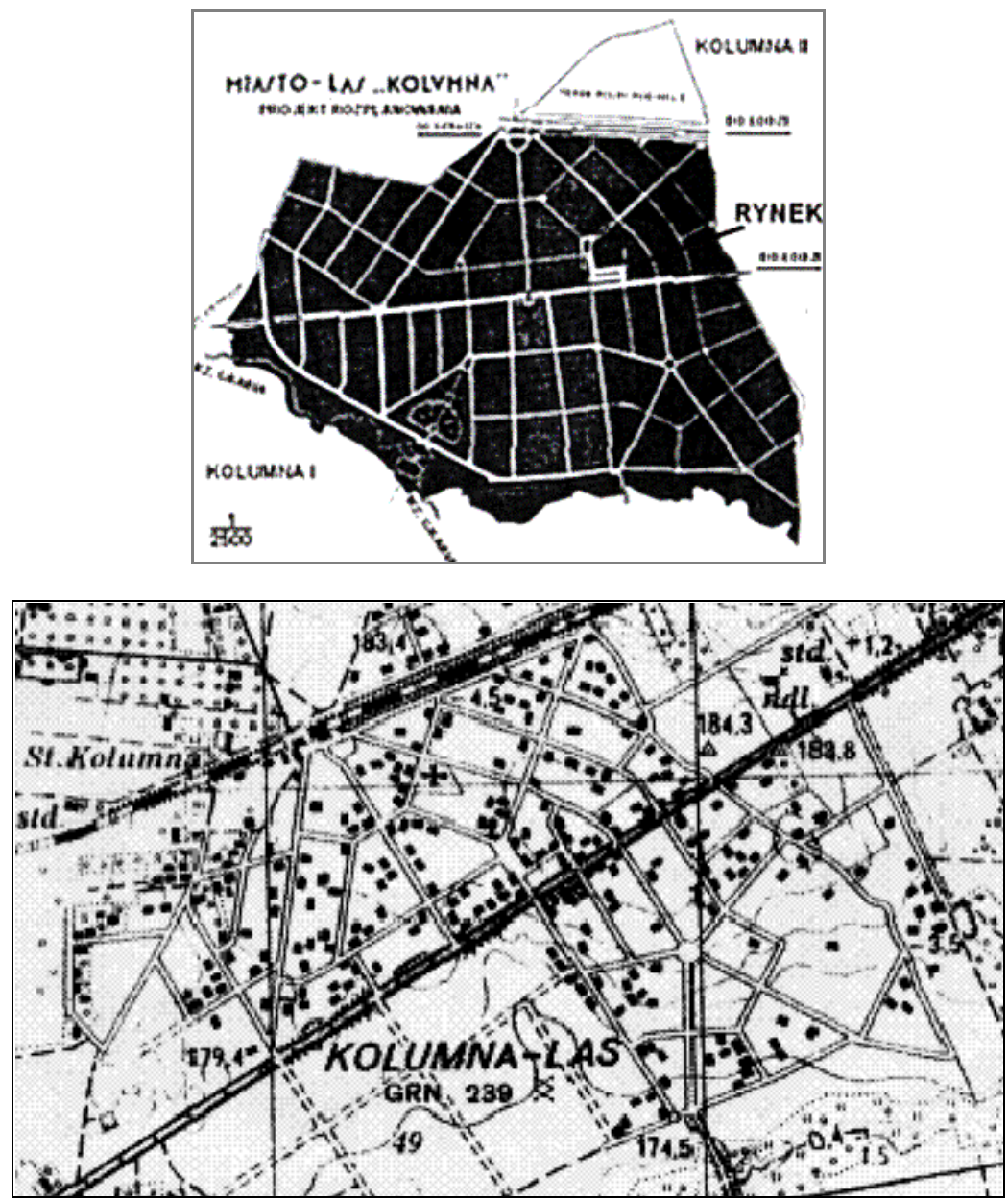

Rys. 6. Planowany (A. Jawornicki, 1927) i rzeczywisty (1937) układ przestrzenny Miasta Lasu Kolumna w okresie dwudziestolecia międzywojennego

Źródło: HejNEMAN (2009); stan z 1937 r. opracowano na postawie Mapy topograficznej w skali 1:50 000, Eask-Zduńska Wola, pas 42, stup 28 (1955) 
Aktywność turystyczna $\mathrm{w}$ tym okresie nie ograniczała się jedynie do wyjazdów letniskowych czy zdrowotnych, lecz zaczęła obejmować także aktywne formy spędzania wolnego czasu. Znamienne jest pojawienie się pierwszych form wypoczynku zbiorowego (kolonie, obozy letnie). Bardzo istotną cechą tego okresu jest powstanie na tym terenie kilku organizacji wspierających (przynajmniej oficjalnie) rozwój turystyki (m.in. Towarzystwo Obrony Środowiska w Grotnikach - 1928 r., Stowarzyszenie Właścicieli Nieruchomości Miasta Ogrodu Sokolniki - 1929 r.) (WŁODARCZYK 1999).

Miasto Las Kolumna powstało w 1927 r. na 113,1 ha majątku J. Szwejcera. Wytyczono 427 działek letniskowych, które zaczęto sprzedawać od 1929 r. po 0,5-2,5 zł za m². Kupowali je przede wszystkim zamożniejsi mieszkańcy Łodzi oraz Pabianic i Łasku - chrześcijanie, co było zalecone przez właściciela gruntu. W wyniku spekulacji nabywcami stawali się jednak z czasem także Żydzi i Niemcy. Zaplanowano ponadto tereny na kościół, rynek i park. W 1931 r. nastąpiła dalsza parcelacja 80,6 ha lasu Szwejcera, w wyniku której wydzielono 298 nowych działek, oraz grunty pod szkołę i park (MATCZAK 1987). Oprócz niedużych domków prywatnych powstawały luksusowe pensjonaty i drewniane wille służące na wynajem jako letniska (rys. 6).

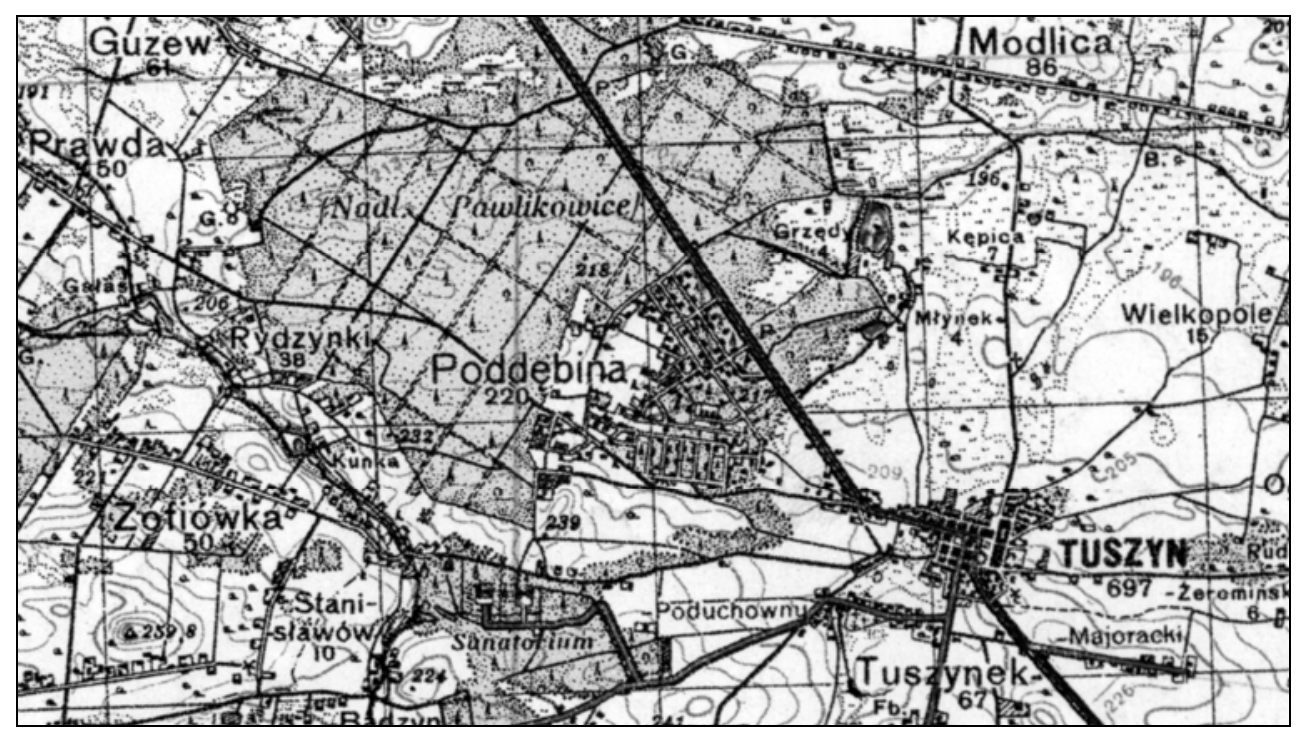

Rys. 7. Rozplanowanie letniska Tuszyn Las (Poddębina) w 1937 r. w układzie parkowym. Na mapie widoczne także starsze miejscowości letniskowe Zofiówka i Rydzynki oraz sanatorium w Tuszynku

Źródło: Mapa topograficzna w skali 1:100 000, ark. Pabianice, pas 42, stup 29 (1937) 
Plany utworzenia Tuszyna Lasu sięgają 1927 r., jednak sprzedaż przygotowanych przez Radę Miejską 615 działek na obszarze 116 ha rozpoczęto w 1928 r. (rys. 7, fot. 1 i 2). Posesje o powierzchni ok. $1200 \mathrm{~m}^{2}$ kosztowały 1-6 zł za m², ale można było kupić najwyżej trzy na osobę. Statut osiedla, aby utrzymać jego letniskowy charakter, zezwalał na wycięcie jedynie do $33 \%$ drzewostanu każdej z parceli (SZYMANEK-SZEFLIŃSKA 2011). Nabywcami wtórnymi (prawo pierwokupu mieli tylko mieszkańcy Tuszyna pochodzenia polskiego) byli przede wszystkim łodzianie pochodzenia żydowskiego (ortodoksyjni; zwłaszcza w południowej części osiedla, na tzw. Palestynce) i niemieckiego oraz mieszkańcy Pabianic.
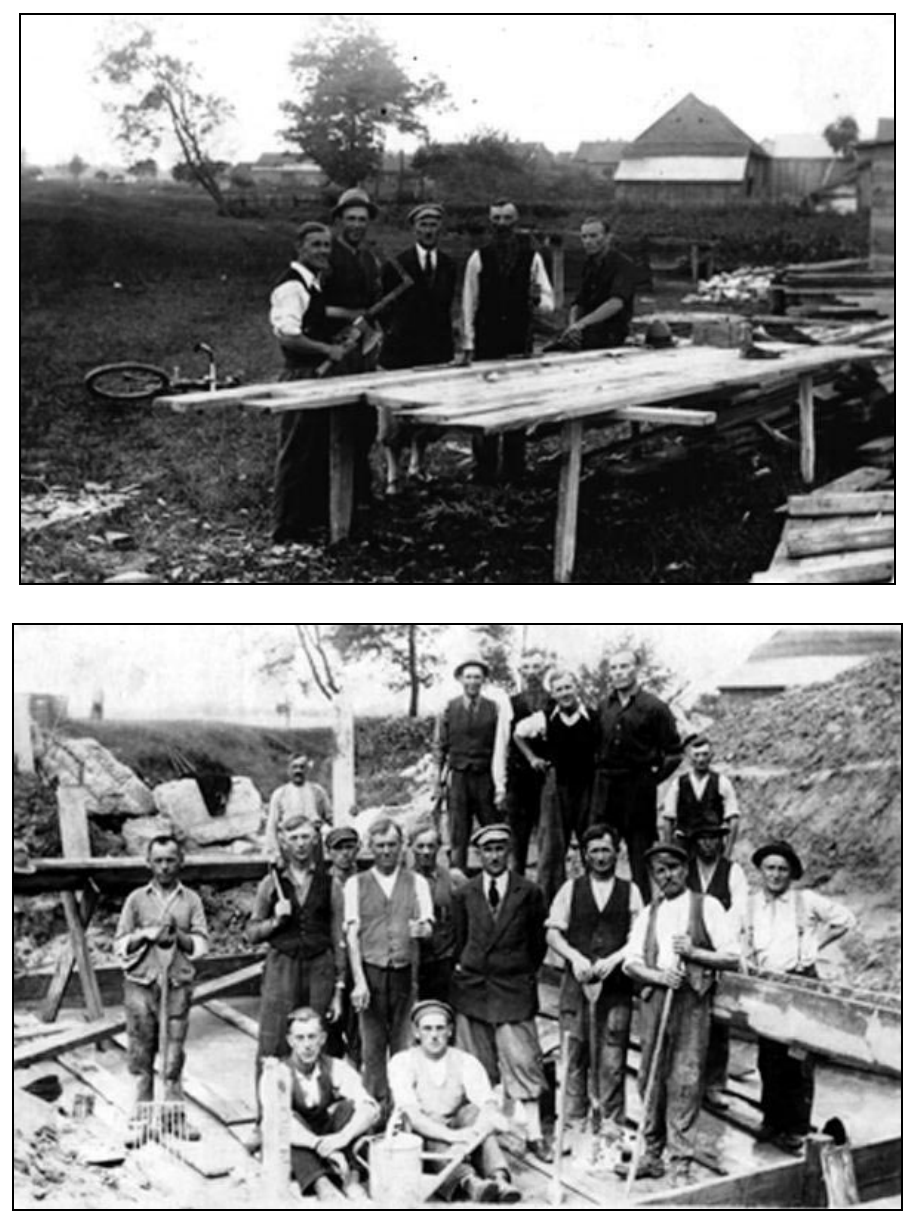

Fot. 1 i 2. Budowa Tuszyna Lasu - fot. ze zbiorów Tomasza Kotlickiego Źródło: SZYMANEK-SZEFLIŃSKA (2011) 
W swoim opracowaniu Szymanek-Szeflińska (2011) pisze m.in.:

„Przystąpiono do sprzedaży działek i zgodnie z projektem planu inż. A. Kartasińskicgo przygotowano w tym celu 615 działek. Ulgami przy nabywaniu placów miano objąć mieszkańców Tuszyna, urzędników państwowych, sejmikowych i miejskich. Dla pracowników magistratu przewidziano (zabezpieczyć) po jednym placu ulgowym, przewidując zniżkę $20 \%$ od zasadniczej ceny szacunkowej, z prawem spłaty całej sumy $\mathrm{w}$ przeciagu 5 lat. Zgodnie ze sporządzonym planem inż. A. Kartasińskiego główną ulicą osiedla letniskowego Tuszyn - Las miała być aleja 3 Maja (dziś również 3 Maja), a punktem centralnym plac Legionów z pamiątkowym obeliskiem. Zaprojektowano również cztery parki o nazwach: J. Piłsudskiego, J. Kilińskiego, Wolności i Olszynki.

W 1936 r. podjęto próbę uznania Tuszyna Lasu za miejscowość kuracyjną która zakończyła się niepowodzeniem. Rada Miejska i Zarząd Miejski pod przewodnictwem burmistrza T. Zwierzyńskiego, po wielu konsultacjach z Otwockiem, Ciechocinkiem, Zakopanem opracował Statut dla osiedla kuracyjnego w Tuszynie Lesie. Statut opracowano bardzo starannie, wręcz drobiazgowo, uwzględniając ulgi w opłatach dla dzieci, wojskowych, inwalidów, dziennikarzy, dla uczestników obozów i kolonii. Ponadto przygotowano szczegółową charakterystykę Poddębiny, TuszynaLasu i Schodowej Góry.

Rada Miejska w uchwale nr 11/1937 przedstawiła następującą motywację, która miała zadecydować o uznaniu Tuszyna Lasu, Poddębiny i Schodowej Góry za miejscowości o charakterze kuracyjnym.

A oto motywacja:

1. miejscowości posiadają doskonałe warunki klimatyczne,

2. dobry dojazd z Łodzi (tramwaj).

3. zabudowa willowa - każda willa posiada studnię z dobrą wodą do picia,

4. przy każdej willi jest $1000 \mathrm{~m}^{2}$ lasu sosnowego,

5. ulic jest 33, częściowo z chodnikami i uporządkowaną nawierzchnia,

6. miejscowości posiadają oświetlenie elektryczne,

7. ogólna liczba domów w Poddębinie wynosi 74, w Tuszynie Lesie 150, razem 224, z których 200 jest letniskowych,

8. liczba osób przybywających na sezon letni wynosiła:

a) w $1934-5600$,

b) w $1935-5700$,

c) w 1936-5000; letnicy przeważnie przybywają z miasta Łodzi,

9. w porze letniej czynnych jest 5 pensjonatów, z których przeciętnie korzysta 150 osób, a jeden pensjonat czynny jest cały rok (w porze jesiennej i zimowej korzysta średnio 30 osób) są to: «Grant Pensjonat», Pensjonat «Mrówka», Pensjonat «Marta», dwa pensjonaty w Poddębinie (Rodzin 
Policyjnych i Żydowskich) pensjonaty w «Poddębinie» z nowoczesnym kąpieliskiem zwanym «mykwą».

10. w czasie sezonu czynnych jest sześć gabinetów lekarskich i trzy dentystyczne,

11. zaopatrzenie również dobre, działa 25 sklepów spożywczych, 3 piekarnie, 6 sklepów rzeźniczych,

12. zapewniona jest również godziwa rozrywka w dwóch ośrodkach (Grant Pensjonacie i u braci Tylińskich)."

Zaprezentowany cytat oddaje charakterystyczną sytuację nie tylko Tuszyna Lasu, ale także innych podłódzkich miejscowości, które pełniły w tym czasie funkcję letniskową.

W 1928 r. rozpoczął się pierwszy etap parcelacji 30 ha sokolnickiego majątku barona Aleksandra Rostockiego. Działki o powierzchni średnio $1000 \mathrm{~m}^{2}$ sprzedawano po 60-85 gr. za m², przy czym można było wpłacić jedynie $25 \%$ ceny, a resztę spłacać w 11 ratach miesięcznych bez oprocentowania. Niska cena, która kształtowała się w granicach 3-4 miesięcznych pensji nauczyciela czy wykwalifikowanego robotnika, miała zachęcić do kupna nieruchomości wszystkich zainteresowanych, również instytucje, np. stowarzyszenia, urzędników państwowych czy organizacje zawodowe. Z uwagi na duże zainteresowanie gruntami sokolnickimi w krótkim czasie dokonano kolejnej parcelacji dóbr barona, w wyniku czego powstało regularne, o powierzchni ponad 346 ha, leśne osiedle o nazwie Miasto Ogród Sokolniki (rys. 8).

$\mathrm{Na}$ parcelację swojego podłódzkiego majątku zdecydował się w $1930 \mathrm{r}$. także hrabia Kazimierz Rzewuski, wytyczając na obszarze leśnym Głowna 127 działek, na których zakazał ich wtórnego podziału i wycinki więcej niż $1 / 3$ drzewostanu. Kupnem działek letniskowych zainteresowani byli przede wszystkim łódzcy i brzezińscy Żydzi, którzy z czasem zagospodarowali osiedla Nowe Zakopane i Nowy Otwock (LISZEWSKI 1987). W Głownie oprócz wypoczynku indywidualnego na działkach, rozwijał się także wypoczynek zorganizowany $\mathrm{w}$ pensjonatach i willach letniskowych oraz kolonijny dla dzieci z Łodzi.

Po 1930 r. nastąpiła na dużą skalę sprzedaż gruntów leśnych w Wiśniowej Górze (rys. 9). Były one przedmiotem zainteresowania głównie Żydów, którzy wznosili tam domy letniskowe i pensjonaty oraz zbudowali ośrodek wypoczynkowy z basenem. Na letnisko do Wiśniowej Góry przyjeżdżali przede wszystkim średniozamożni łodzianie pochodzenia żydowskiego, ponieważ wypoczynek nie był tu tak drogi jak w innych miejscowościach z uwagi na niedużą odległość od Łodzi i brak zbiorników wodnych. 


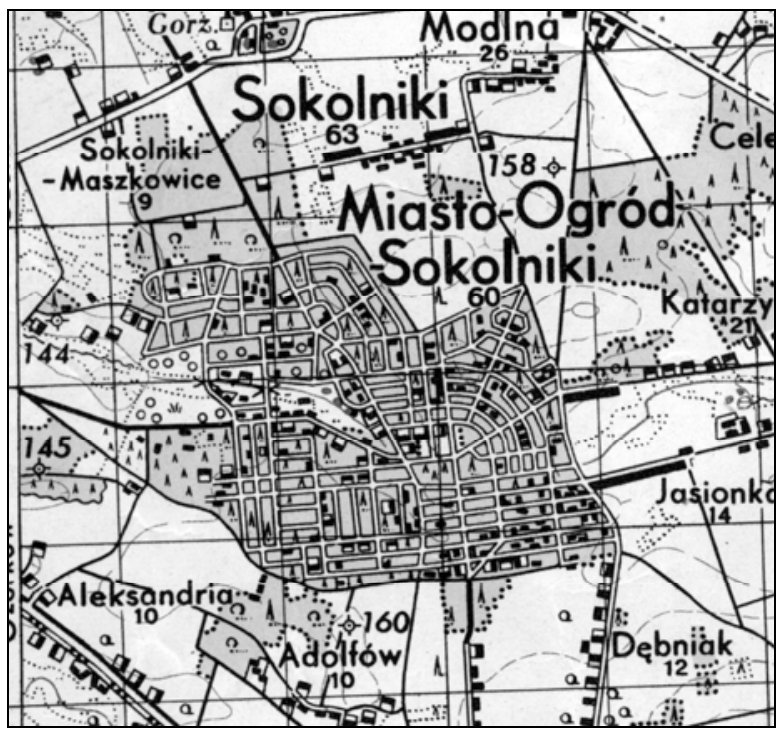

Rys. 8. Stan realizacji Miasta Ogrodu Sokolniki w 1937 r. Zródło: opracowano na postawie Mapy topograficznej w skali 1:50 000, Łódź, pas 41, słup 29 (1955)

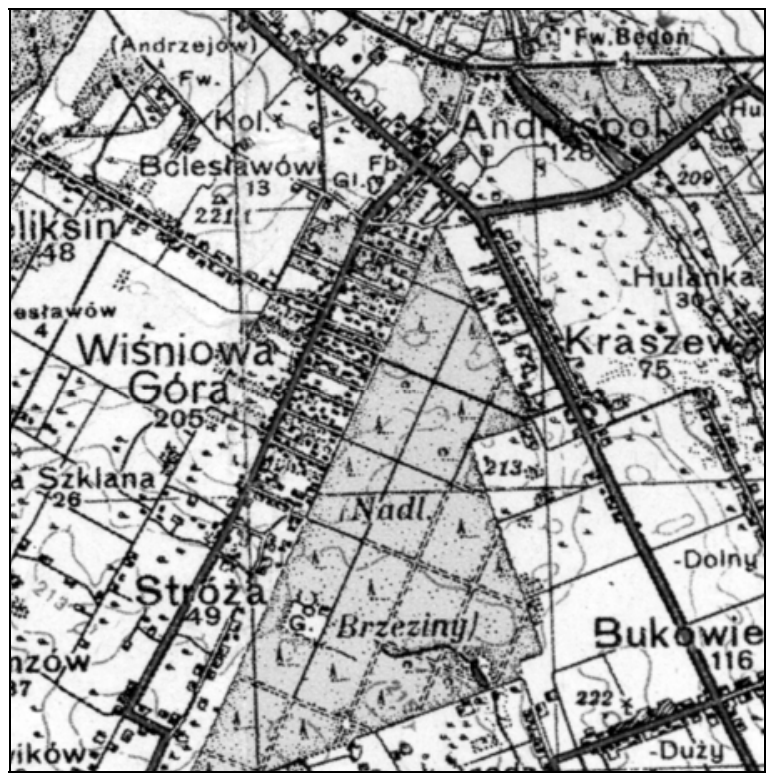

Rys. 9. Rozplanowanie letniska Wiśniowa Góra w 1937 r. w układzie jednoosiowym(wg Matczaka 1984)

Źródło: Mapa topograficzna w skali 1:100 000, ark. Pabianice, pas 42, stup 29 (1937) 
Próby realizacji inwestycji letniskowych i mieszkaniowych o charakterze miast ogrodów podjęte zostały na terenach będących obecnie $\mathrm{w}$ granicach administracyjnych Łodzi (Ruda, Łagiewniki). Działania takie podjęte zostały m.in. przez Irenę Kermenic (wnuczkę J. Heinzla), właścicielkę tzw. Łagiewnik B, oraz przez władze miasta Łodzi, które wykupiły z rąk prywatnych właścicieli część tzw. Łagiewnik A. Jednakże spory co do sposobu zagospodarowania całego obszaru Lasu Łagiewnickiego (I. Kermenic - działki letniskowe, władze miasta - osiedle mieszkaniowe) przedłużały wydanie decyzji przez Okręgowy Urząd Ziemski. W rezultacie realizowane miały być oba pomysły (rys. 10). Z powodu istniejącego w tym czasie poważnego kryzysu gospodarczego, a co za tym idzie trudności finansowych, ani wspomniane wcześniej, ani późniejsze próby parcelacji terenów należących do W. Grossmana nie doszły do skutku (STEFAŃSKI 1991).

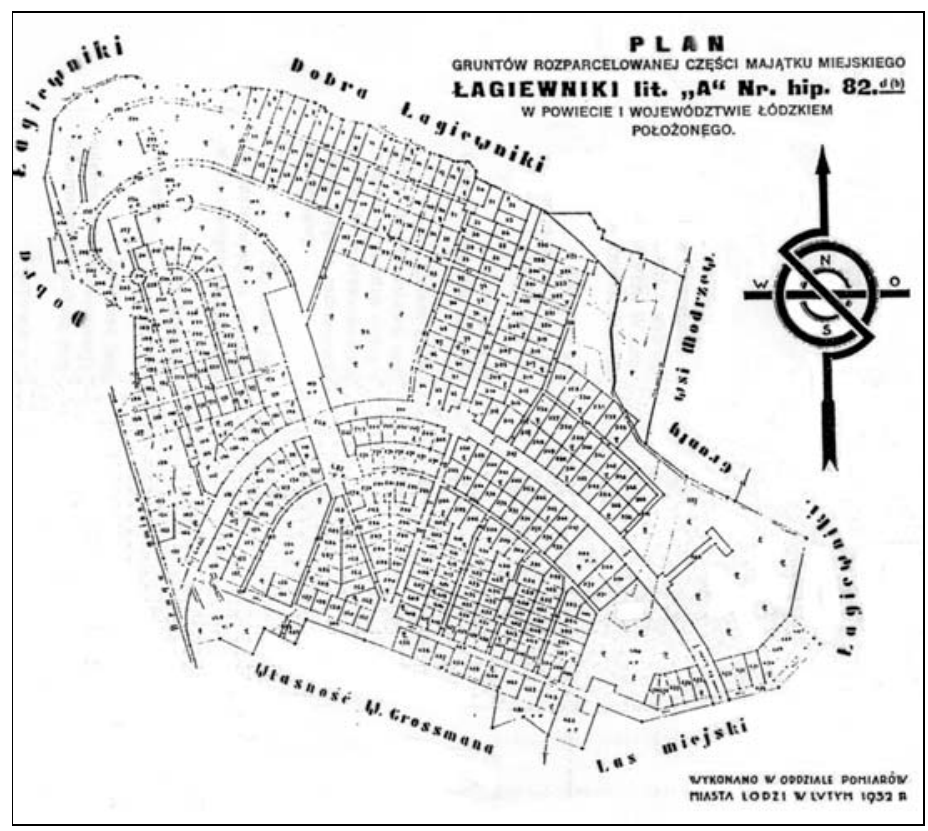

Rys. 10. Plan miasta lasu Łagiewniki - projekt z 1932 r. Źródło: STEFAŃSKI (1991)

Jedyną zrealizowaną inwestycją na terenie Lasu Łagiewnickiego była otwarta uroczyście w 1935 r. droga łącząca miasto z nowym osiedlem mieszkaniowym (obecnie ulica Wycieczkowa). Z całości przedsięwzięcia pozostały jedynie ambitne projekty Miasta Lasu Łagiewniki, świadczące o dużym roz- 
machu, funkcjonalności i dbałości o efekty estetyczno-krajobrazowe projektu (rys. 11). Powiodły się natomiast projekty utworzenia "zielonych osiedli” w nieco dalszej odległości od Łodzi. Powstały w tym okresie Grotniki (z parcelacji gruntów należących do Jasieńskich - 38 ha w 1925 r. i Jungowskich w 1928 r.), Lućmierz Las (Rosanów) (na gruntach leśnych należących do Towarzystwa Przemysłowego Leśmierz - po wschodniej stronie linii tramwajowej Łódź-Ozorków) oraz Miasto Ogród Sokolniki (na gruntach A. Rostockiego - początkowa parcelacja 30 ha gruntu - 300 działek, miała miejsce w na przełomie lat 1928/29) (WŁODARCZYK 1999).

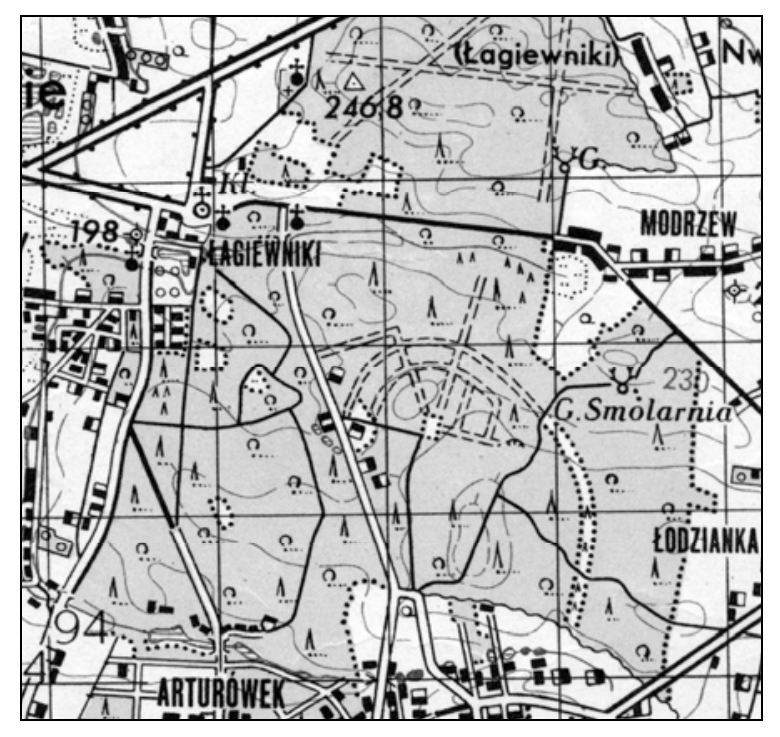

Rys. 11. Stan realizacji Miasta Lasu Łagiewniki w 1937 r. Źródło: opracowano na postawie

Mapy topograficznej w skali 1:50 000, Łódź, pas 41, słup 29 (1955)

Działki letniskowe i domy rekreacyjne powstawały również na terenach podmiejskich znanych z wcześniejszych, przedwojennych wyjazdów na letniska. W tych starszych miejscowościach funkcja wypoczynkowa współwystępowała niekiedy $\mathrm{z}$ innymi (np. z mieszkaniową), zaś w nowych była dominująca. Tym sposobem ukształtowana sieć osadnicza wokół Łodzi wzbogaciła się w międzywojniu o nowy element, jakim było osadnictwo wypoczynkowe. To ono przyczyniło się do dynamicznej ekspansji funkcji letniskowej na tereny podmiejskie $\mathrm{w}$ tym okresie.

Lata 1936-1939 przyniosły ciągły proces powiększania się obszarów kolonizacji turystycznej (parcelacje nowych obszarów leśnych), a także dodat- 
kowe połączenia z Łodzią w sezonie letnim (tzw. „zielone linie”). Stale i dynamicznie wzrastał ruch turystyczny szacowany już na kilka tysięcy w ciągu roku. Obserwowano w tym czasie dalszy rozwój zarówno ruchu indywidualnego, jak i grupowego. Ten ostatni obejmował przede wszystkim wyjazdy kolonijne młodzieży zrzeszonej w YMCA oraz obozy harcerskie. Część zabudowy zmieniła funkcję z obiektów letniskowych (zgodnie z wcześniejszą idea „miast ogrodów”) na miejsca stałego zamieszkania. Tym samym zwiększała się liczba stałych mieszkańców tych miejscowości. Pojawiało się także coraz więcej domów letniskowych. Obok tradycyjnych już form aktywności turystycznej w okresie tym dynamicznie rozwijały się przyjazdy niedzielne ludności mniej zamożnej, nieposiadającej działek letniskowych (WŁODARCZYK 1999).

Planowo zakładane w okresie międzywojennym osiedla wypoczynkowe charakteryzowały się regularnym układem przestrzennym, nawiązującym do wspomnianej wcześniej idei miast ogrodów E. Howarda, a także dużą różnorodnością fizjonomii zabudowy.
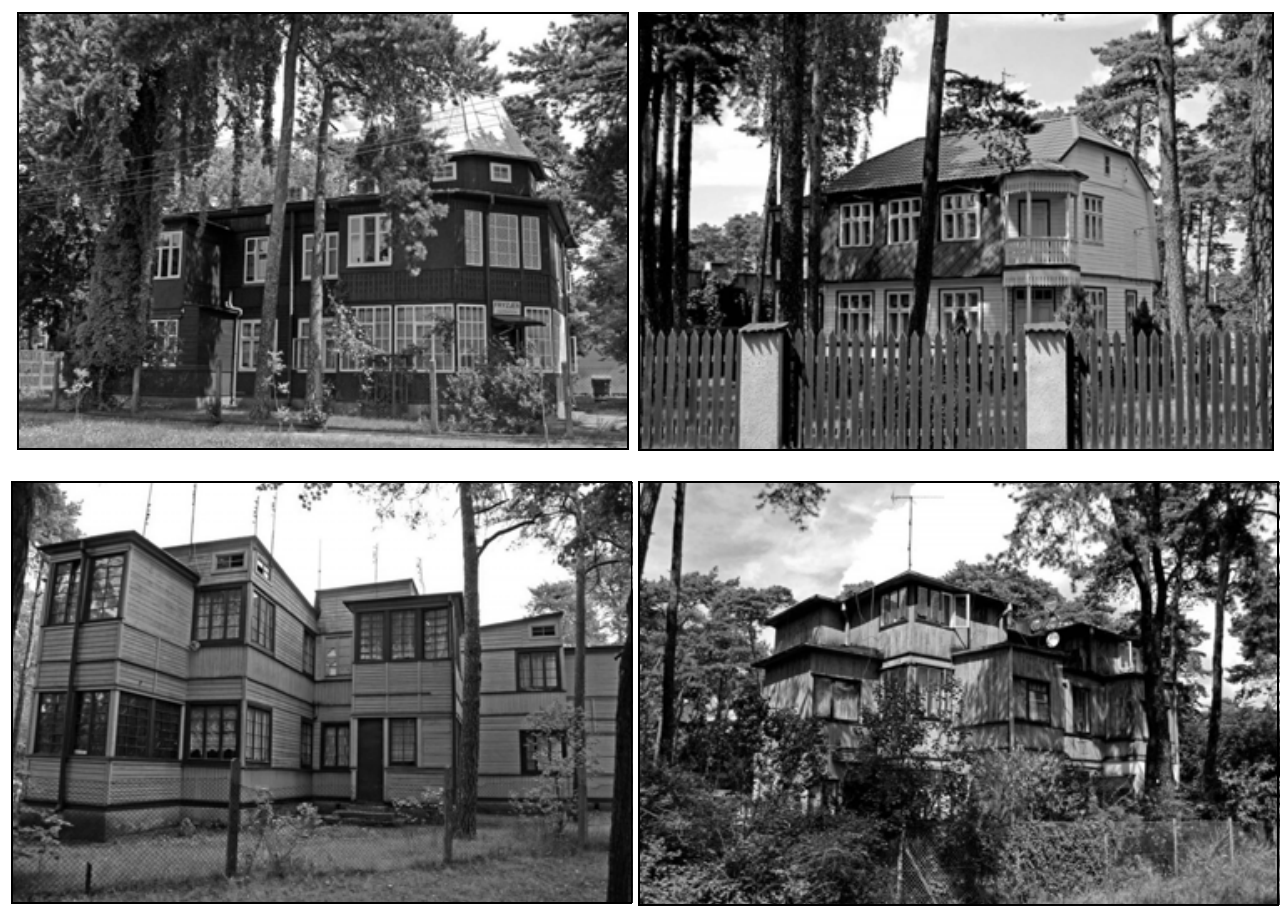

Fot. 3-6. Zabudowa letniskowa z okresu do 1939 r. na przykładzie Lasu Kolumny (fot. W. Witoński, 2011) Źródło: www.lask.pl 
Domy letniskowe w okresie międzywojennym wznoszono przede wszystkim z drewna. MATCZAK (1986) wyróżnił trzy ich typy. Ekskluzywne, sosnowe lub modrzewiowe, wille o dużych powierzchniach użytkowych miały charakter letnich rezydencji dla najzamożniejszych właścicieli. Budowano je przeważnie we wschodniej i południowej części strefy podmiejskiej Łodzi, m.in. w Andrzejowie, Tworzyjankach, Tuszynie, Kolumnie (fot. 3-6). Charakteryzowały się ciekawą formą architektoniczną z rzeźbionymi obramowaniami drzwi i okien. Okazałe, drewniane, zwykle dwukondygnacyjne pensjonaty liczyły wiele izb, które udostępniano na wynajem. Budynki te miały przeszklone przybudówki - werandy, liczne duże okna, wielokrotnie łamane i spadziste dachy. Przykłady takiej architektury można spotkać np. w Wiśniowej Górze, Sokolnikach Lesie i Kolumnie. Mniejsze (3-6-izbowe) i znacznie skromniejsze pod względem architektury domy letniskowe występowały najpowszechniej. Służyły one jako letnie kwatery rodzinom kupców, rzemieślników i urzędników. Budowane z desek sosnowych, bez dodatkowych ozdób, na podmurówce, miały zwykle 1,5-2 kondygnacji.

W okresie tym prowadzono także zakrojoną na szeroką skalę akcję propagandową (dziś powiedzielibyśmy promocyjną), która miała nakłonić do zakupu nieruchomości lub do przyjazdu na wypoczynek. W tym celu drukowano ogłoszenia w lokalnych i regionalnych gazetach, przygotowywano plakaty i ulotki (rys. 12).
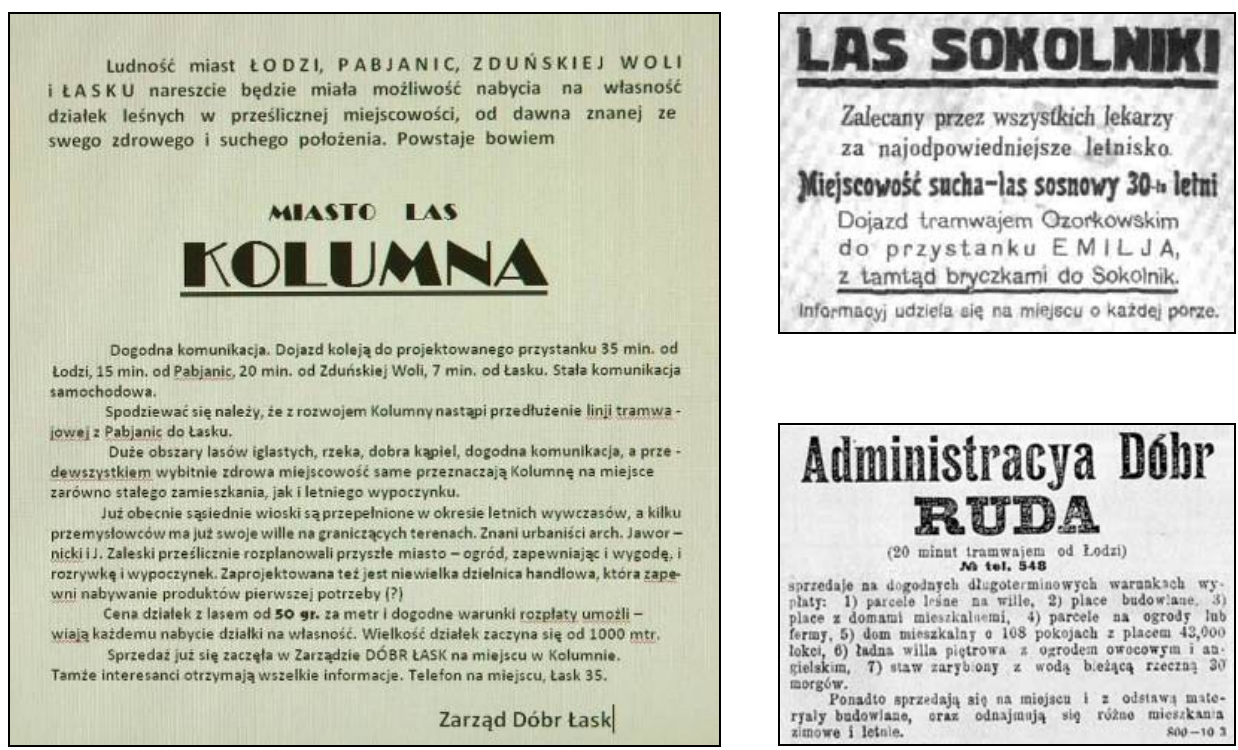

Rys. 12. Ogłoszenia o sprzedaży gruntów i nieruchomości na cele letniskowe w okolicach Łodzi Źródło: HEJNEMAN (2009), ŁUNIEWSKI (2000), STAWISZYŃSKA (2009) 
Większość działań związanych ze sprzedażą gruntów i tworzeniem miejscowości letniskowych podjętych $\mathrm{w}$ tym okresie umożliwiała Ustawa o wykonaniu reformy rolnej z dnia 28 grudnia 1925 r. (rys. 13).

Część miejscowości zlokalizowanych w strefie podmiejskiej Łodzi wymieniona została w specjalnym wykazie opublikowanym w Dzienniku Urzedowym Województwa Łódzkiego (nr 22) z 1926 r.7 (rys. 14). Należały do nich m.in.: Andrzejów, Helenówek, Ruda Pabianicka, Wiśniowa Góra, Poddębina, Warchołów, Gałkówek i Żakowice.

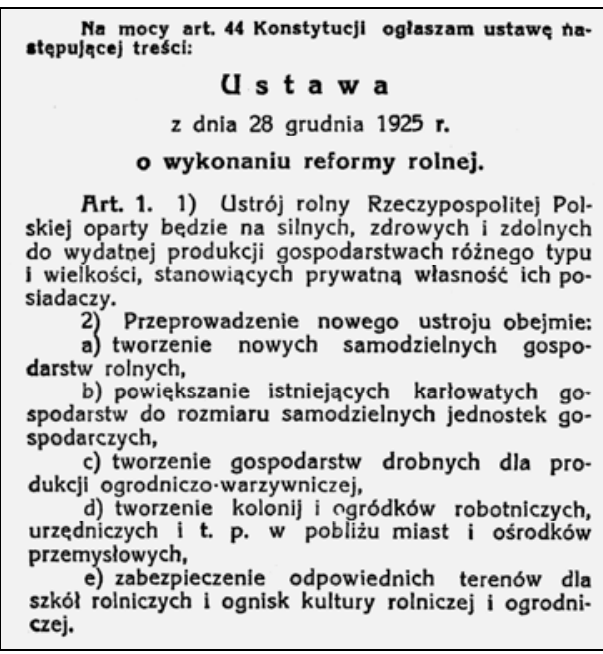

Rys. 13. Fragment Ustawy o wykonaniu reformy rolnej dopuszczającej parcelacje majątków ziemskich w okolicach dużych miast Źródło: materiały archiwalne

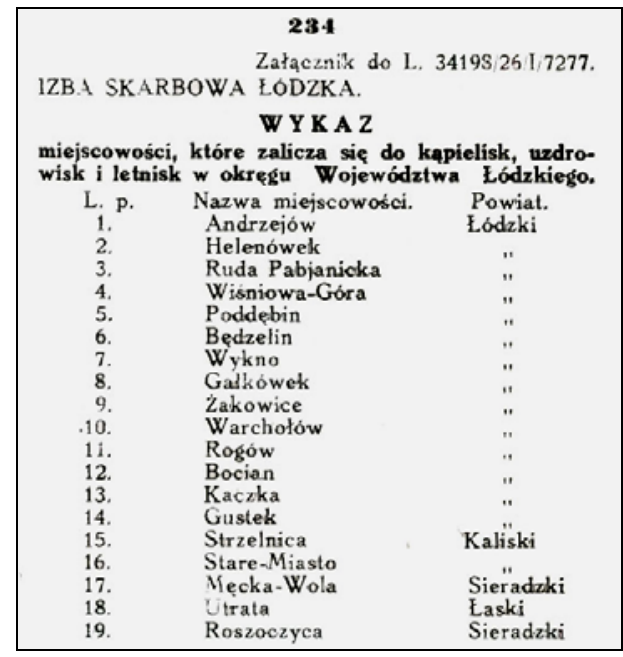

Rys. 14. Wykaz miejscowości zaliczanych do kąpielisk, uzdrowisk i letnisk w okręgu województwa łódzkiego

Źródło: Dz. U. WŁ z 31 maja 1926 r. (nr 22, s. 207)

Okres II wojny światowej oraz dziesięciolecia po wyzwoleniu uniemożliwił rekreację łodzian poza miejscem zamieszkania, powodując ograniczenie lub wręcz zanik funkcji wypoczynkowych w dawnych osiedlach letniskowych położonych $\mathrm{w}$ strefie podmiejskiej. $\mathrm{Z}$ istniejącej infrastruktury w niewielkim stopniu korzystała jedynie ludność niemiecka. Przyczyniły się do tego zniszczenia wojenne, niestabilna sytuacji w kraju i ubóstwo ludności, działania okupantów i wymuszona intensywna urbanizacja wielu wsi letniskowych polegająca na przekształceniu ich w osiedla mieszkaniowe (w daw-

7 Dziennik Urzędowy Województwa Łódzkiego z 31 maja 1926 r. (nr 22, s. 207) upublicznił wykaz 19 miejscowości zaliczanych do kąpielisk, uzdrowisk i letnisk w okręgu województwa łódzkiego. 
nych willach i pensjonatach urządzono prowizoryczne mieszkania i zasiedlono je napływającymi do Łodzi osadnikami i repatriantami). Część podmiejskich rezydencji łódzkich fabrykantów zamieniono natomiast na ośrodki kolonijne lub wczasowe i przekazano je państwowym zakładom pracy na cele socjalne. W wyniku tego obiekty te, tak jak i niektóre miejscowości, całkowicie utraciły swoje pierwotne funkcje letniskowe (MAKOWSKA-ISKIERKA 2009).

\section{Podsumowanie}

Miejscowości letniskowe pojawiły się w strefie podmiejskiej Łodzi już $\mathrm{w}$ pierwszej dekadzie XX w., ale ich największy rozwój miał miejsce w latach międzywojennych, kiedy na skutek dużych parcelacji lasów, głównie w miejscowościach: Kolumna, Tuszyn, Wiśniowa Góra, Sokolniki i w rejonie Grotnik, zaczęły powstawać osiedla zakładane planowo.

Osiedla letniskowe powstawały przede wszystkim z inicjatywy osób prywatnych, a także władz miejskich Łodzi, a w późniejszym czasie także władz wojewódzkich. Planowano zewsząd otoczyć miasto centralne (Łódź) tego typu miejscowościami, ale część z nich, choć były przygotowane projekty, nie doczekała się nigdy realizacji (np. miasto las Łagiewniki).

Lokalizowano je głównie na obszarach porośniętych lasem sosnowym, w niedalekiej odległości od granic Łodzi (20-30 km), w zasięgu dostępności środkami komunikacji szynowej (linie kolejowe i najdłuższa w tym okresie sieć tramwajów podmiejskich w Polsce).

Ich wytyczenie poprzedziły parcelacje terenów leśnych i częściowo rolniczych, które umożliwiała Ustawa o wykonaniu reformy rolnej z $1925 \mathrm{r}$. Miasta lasy (np. Tuszyn, Kolumna) i miasta ogrody (np. Sokolniki) były zakładane w sposób planowy i uporządkowany, na tzw. "surowym korzeniu”, dzięki czemu uzyskały czytelne (w sieci ulic i placów) układy przestrzenne. Realizacje te, pomimo znacznych modyfikacji, niewątpliwie inspirowane były wywodzącą się z końca XIX w. nośną ideą angielskiego urbanisty E. Howarda zakładania ",miast ogrodów”.

Powstawanie osiedli letniskowych w strefie podmiejskiej Łodzi przyczyniało się nie tylko do podniesienia jakości życia mieszkańców dużego miasta, ale także mieszkańców terenów, na których osiedla były lokalizowane. Nowi użytkownicy przestrzeni często zakładali organizacje społeczne aktywizujące lokalne środowisko. 
Większość założeń wywodzących się z okresu międzywojennego, pomimo przemian funkcjonalnych, zachowała do dziś czytelny układ przestrzenny, a we współczesnej zabudowie odnaleźć jeszcze można coraz mniej liczne (niestety) przykłady willi, pensjonatów o charakterystycznej fizjonomii budynków pełniących funkcje wypoczynkowe.

Optymizmem napawa fakt, że lokalne społeczności, nawiązując do międzywojennych tradycji letniskowych, starają się obecnie aktywizować dawne miejscowości wypoczynkowe poprzez próby przywrócenia (przynajmniej częściowo) ich dawnych funkcji.

\section{BIBLIOGRAFIA}

BARANOWSKA M., 2005, Porównanie koncepcji i rozwoju miast ogrodów w Wielkiej Brytanii i w Polsce na wybranych przyktadach (Letchworth, Welwyn Garden City, Las Kolumna, Tuszyn Las, Grotniki, Miasto Ogród Sokolniki, Łagiewniki), mpis pracy magisterskiej w Katedrze Geografii Politycznej i Studiów Regionalnych UŁ, Łódź.

BEDNARSKA U., Musią W., 1973, Zagospodarowanie turystyczne regionu łódzkiego, „Region Łódzki. Studia i Materiały", t. III.

DOBRZYŃSKI W., 1911, Zdrowie publiczne a idea miast ogrodów, „Zdrowie”, odbitka z nr 11, Warszawa.

DoBrZYŃSKI W., 1914, Postępy idei miast ogrodów w Anglii i u nas, „Zdrowie”, odbitka z nr 6-10, R. XXX, Warszawa.

Dziennik Urzędowy Wojezwództwa Łódzkiego z 31 maja 1926 r., nr 22.

HejNEMAN K., 2009, Miasto Las Kolumna i jego historia, www.gazetalaska.pl.

HowARD E., 1965, Garden Cities of To-Morrow, edited with a preface by F.J. Osborn, Introductory essay by L. Mumford, Great Britain.

KIEŁCZEWSKA-ZALESKA M., 1972, Geografia osadnictwa. Zarys problematyki, PWN, Warszawa.

LisZEWSKI S., 1987, Geneza i rozwój osadnictwa wypoczynkowego w otoczeniu Łodzi, „Acta Universitatis Lodziensis. Turyzm", 3, s. 33-54.

LISZEWSKI S., 2005, Metropolitalny region turystyczno-wypoczynkowy. Przykład miasta Łodzi, „Turyzm", 15, 1-2, s. 212-138.

LisZEWSKI S., 2010, Od Łódzkiego Zespołu Miejskiego po Łódzki Obszar Metropolitalny, [w:] S. Liszewski (red.), Obszary metropolitalne we wspótczesnym środowisku geograficznym. 58 Zjazd Polskiego Towarzystwa Geograficznego, t. 1. Polskie Towarzystwo Geograficzne, Wydział Nauk Geograficznych UŁ, Łódź, s. 53-66.

ŁUNIEWSKI J., 2000, Dzieje Sokolnik, czyli wspomnienia mieszkańca, OWR Sagalara, Łódź.

MAKOWSKA M., 2002, Przemiany funkcji turystyczno-wypoczynkowej Miasta ogrodu Sokolniki, mpis pracy magisterskiej, w Katedrze Geografii Miast i Turyzmu UŁ, Łódź.

MAKOWSKA-ISKIERKA M., 2009, Procesy urbanizacyjne na terenach turystyczno-wypoczynkowych strefy podmiejskiej Łodzi, mpis pracy doktorskiej, Instytut Geografii Miast i Turyzmu UŁ, Łódź.

Mapa topograficzna w skali 1:100 000, ark. Łódź, pas 41, stup 29, 1939, WIG, Warszawa.

Mapa topograficzna w skali 1:100 000, ark. Ozorków, pas 41, stup 28, 1930, WIG, Warszawa.

Mapa topograficzna w skali 1:100 000, ark. Pabianice, pas 42, stup 29, 1937, WIG, Warszawa. 
Mapa topograficzna w skali 1:50 000, Eódź, pas 41, stup 29, 1955, Sztab Generalny WP.

Mapa topograficzna w skali 1:50 000, Zduńska Wola, pas 42, stup 28, 1955, Sztab Generalny WP.

MATCZAK A., 1981, Tereny wypoczynkowe w strefie podmiejskiej Łodzi, „Miasto”, 31, 6, s. 9-14.

MAтCZAK A., 1982, Funkcja wypoczynkowa strefy podmiejskiej Łodzi, mpis pracy doktorskiej, w Zakładzie Geografii Miast i Turyzmu UŁ, Łódź.

MatczaK A., 1984, Próba wykorzystania analizy morfologicznej do określenia funkcji wypoczynkowej osiedli w strefie podmiejskiej Łodzi, „Problemy Turystyki”, 2, s. 93-97.

MAтсZAK A., 1986, Budownictwo letniskowe w strefie podmiejskiej Łodzi, "Acta Universitatis Lodziensis. Folia Geographica", 7, s. 137-166.

MatczaK A., 1987, Próba określenia funkcji wypoczynkowej osiedli podmiejskich na przykładzie Kolumny, "Acta Universitatis Lodziensis, Turyzm”, 3, s. 55-85.

PRZYBYsz A., 2009, Puszczykowo, miasto ogród, Biblioteka Miejska w Puszczykowie, Puszczykowo.

SMOGORZEWSKI J., 1965, Brwinów, Milanówek i Podkowa Leśna jako podmiejskie osiedla-satelity Warszawy. Zarys rozwoju przestrzennego i funkcjonalnego, IUiA, Warszawa.

STAWISZYŃSKA A., 2009, Ruda Pabianicka - echa przeszłości, Dom Wydawniczy „Księży Młyn”, Łódź.

STEFAŃSKI K., 1991, Miasta ogrody i kolonie letniskowe w strefie podmiejskiej aglomeracji łódzkiej w latach 1925-1939, Zeszyty Naukowe PŁ, Łódź.

STEJSKAє J., 1992, Podmiejskie rezydencje burżuazji łódzkiej i ich funkcje wypoczynkowe dawniej i obecnie, ,Turyzm”, 2, 2.

SZKUP R., 2003, Kształtowanie podmiejskiej przestrzeni wypoczynkowej. Przykład zachodniego sektora strefy podmiejskiej Łodzi, Wyd. Uniwersytetu Łódzkiego, Łódź.

SZYMANEK-SZEFLIŃSKA E. M., 2011 Geneza powstania i założenia miasta (lasu) ogrodu. (Tuszym Las) www.canna.pl/tuszyn/index.php?page=historia_ogrod.

Ustawa o z dnia 28 grudnia 1925 r. o wykonaniu reformy rolnej.

WARSZYŃSKA J., JACKOWSKI A., 1978, Podstawy geografii turyzmu, PWN, Warszawa.

WILUŚ R., LISZEWSKI S., 2010, Region łódzki w nowej koncepcji regionalizacji turystycznej Polski, [w:] Obszary metropolitalne we wspótczesnym środowisku geograficznym, t. 2, 58 Zjazd Polskiego Towarzystwa Geograficznego, Łódź, s. 235-250.

WŁoDARCZYK B., 1999, Przemiany form aktywności turystycznej - przykład krawędzi Wyżyny Łódzkiej, „Szlakami Nauki”, 29, Łódzkie Towarzystwo Naukowe, Łódź.

WOJALSKI M., 1998, 100 lat łódzkich tramwajów, TOnZ Oddział w Łodzi, Zora, Łódź.

www.cyberium.co.uk/park history/welwyn.html.

www.hertfordshire-genealogy.co.uk/data/places/letchworth.html.

www.lask.pl.

www.warszawa.sarp.org.pl. 